\title{
Engaging in a newspaper cartoon thematic analysis to understand the socioeconomic, health, political, and environmental impact of COVID-19 in Sri Lanka
}

\author{
Original Research \\ Thushari Damayanthi Dassanayake ${ }^{1}$, Sarath Rathnayake ${ }^{1}$, Sujeewa Dilhani Maithreepala ${ }^{1}$, Nimanthika Sanjeewani ${ }^{2}$ \\ ${ }^{1}$ Department of Nursing, Faculty of Allied Health Sciences, University of Peradeniya, Sri Lanka; ${ }^{2}$ Vidu Aruna Maha \\ Vidyalaya, Anuradhapura, Sri Lanka
}

Corresponding author: T. D. Dassanayake1 (damayanthi74@ahs.pdn.ac.lk)

\begin{abstract}
Introduction: COVID-19 has become a crisis in Sri Lanka, where prevention is the priority. A lack of knowledge about the virus, however, has resulted in some Sri Lankans not complying with health regulations established to control the spread of COVID-19. Newspaper cartoons are an effective means of communicating important social concerns and have been used at length to do so during the pandemic. Method: An exploratory content analysis of newspaper cartoons was conducted between March 15th and April 15th of 2020 at the beginning of the COVID-19 outbreak in Sri Lanka. A sample of 87 cartoons from eight daily online newspapers were included and were selected using the following keywords: "corona," "COVID-19," or "Sri Lanka." Thematic analysis was used to identify the different perspectives of the cartoons. Results: Thirteen common themes were identified, ranging from identifying COVID-19 as a pandemic, to outlining pandemic-related changes in socio-cultural practices, and categorizing the economic and political impact of the pandemic. Conclusion: Newspaper cartoons were used to convey health messaging to the public during the COVID-19 outbreak in Sri Lanka in ways that were easily recognizable and relatable. They can be used as an effective mode of disseminating information during a crisis.
\end{abstract}

\section{KEYWORDS}

Cartoon Thematic Analysis, COVID-19, Dissemination, Health Message, Social Concerns

\section{INTRODUCTION}

The media has enormous potential to influence health-related behaviours and perceptions and plays a crucial role in how the public responds to viral outbreaks around the world (Leask, 2016; Wakefield, Loken, \& Hornik, 2010). It can be very effective at informing, motivating, and empowering the public through print, television, radio and the internet (Leask, 2016; Leask, Hooker, \& King, 2010; MaryonDavis, 2012; Nghiem, Leung, Cleghorn, Blakely, \& Wilson, 2019). As one of the oldest forms of mass media, cartoons show human communication based on the cartoonist's "conceptualisation of subjectivity" (Kwon, 2019, p12). Cartoons are multimodal, consisting of representations of verbal expressions as well as non-verbal pictorial, mostly satirical images to deliver a specific message (Kawakib, Muhammad, \& Fathi, 2016; Kwon, 2019). A cartoon is a simple communication method that can increase the attention of people relative to text or other visual clues (Kirkpatrick et al., 2019).

The use of cartoons in disseminating information has been shown to be more effective than text alone (Green \& Myers, 2010; Houts, Doak, Doak, \& Loscalzo, 2006). Cartoons can be categorised into three nonverbal types: visual puns (PUN), semantic cartoons (SEM) and theory of mind cartoons (TOM) (Andrea, 
2012). Visual puns are drawings without any text. They are based on visual resemblance, and do not require the viewer to empathize in order to understand the cartoon (Tschacher, Genner, Bryjová, Schaller, \& Samson, 2015) (Figure 1). In semantic cartoons (SEM), the punch line is based on semantic relations between two scripts or meanings. Empathising or systemising is needed to understand the meaning (Perchtold-Stefan et al., 2020) (Figure 2). In Figure 2, the reader can understand how medical staff carry/handle the world during this pandemic. In order to achieve this understanding, the reader needs to critically analyse the cartoon.

In Theory of Mind cartoons (TOM), an appropriate mental state will be attributed to one or more characters (Gallagher et al., 2000) (Figure 3). Visual Puns (PUN) do not require mentalizing or empathizing abilities to be understood. Semantic cartoons (SEM) are based on semantic relationships and can be understood by either empathizing or systemizing. Theory of Mind (TOM) cartoons are processed differently from other two types of cartoons. Interpretive abilities are required to process TOM cartoons. In Figure 3, the reader can assume that the symbol representing COVID -19 as a racer is moving too fast for the 2020 Olympics to be held safely.

In the early 19th century, political cartoons emerged as an important visual communication method. A drawn picture or cartoon was used to summarise or comment on the important social events in newspapers in the pre-photographic period (Wiid, Pitt, \& Mills, 2012). Cartoons have been used to present various perspectives on political scandals, sexual rumourmongering, conflicts, victories, defeats, disasters, and economic turmoil (Wiid et al., 2012). They can reflect both what is happening in contemporary society and what people are thinking about it (Nwabueze C, Igboeli C, \& U., 2017; Wiid et al., 2012).

Since the World Health Organisation (WHO) declared the COVID-19 outbreak as a "Public Health Emergency of International Concern (PHEIC)" (Zhang et al., 2020), the virus has spread exponentially in both developed and developing countries. Sri Lanka, a developing island country in South Asia, has been hit hard by COVID-19, and the toll continues to grow. Sri Lanka has taken public health measures necessary to control the spread of the disease, based on WHO guidelines, with adaptive strategies that encourage community resilience, social connection, protecting incomes and maintaining a secure food supply. In Sri Lanka, COVID-19 was documented and publicized in mass media and social networks, and the messaging was largely built on images. Cartoons, in particular, are an effective and insightful means to explore the unfolding of the COVID-19 crisis in Sri Lanka. Therefore, this paper aims to explore the different viewpoints expressed in cartoons that delineate the COVID-19 pandemic, including its health, social, economic and political impacts that relate to public health in Sri Lanka.

\section{METHODS}

\section{Study Design}

An exploratory content analysis of newspaper cartoons concerning the COVID-19 outbreak was conducted.

\section{Selection of Cartoons}

Cartoons were selected from the daily newspapers published online in Sri Lanka. Seven newspapers, representing Sinhala (Lankadeepa, Ada, Mawbima), Tamil (Virakesari) and English (Island, Ceylon Today and Daily Mirror) languages were selected. In the selection of cartoons, the terms "corona", "COVID19", or "Sri Lanka" were used. All cartoons published between March 15th and April 15th, 2020, that met the above key terms were extracted by the first author (DD). After removing the duplications, the cartoons were screened by two authors (DD and SM) based on the key terms. Agreement between two authors was assessed based on Cohen's Kappa value.

\section{Data Extraction}

An Excel data sheet was developed for data extraction and included the name of the newspapers, date, type of cartoons, symbolism, and pertinent information depicted.

\section{Data Analysis}

The SHOWeD framework originally used for image analysis was adapted to analyse the information 
depicted in the cartoons (Novak, 2010). This framework consists of five questions: (1) what do you see here? (2) what is really happening here? (3) how does this relate to our lives? (4) why does this problem or strength exist? and (5) what can we do about this? (Gant et al., 2009; Novak, 2010; Wang, Burris, \& Ping, 1996). As a pilot analysis, based on this five-step framework, ten cartoons were analysed by all authors. The supplementary electronic material item 1 shows the detail of the process. Problems and differences in interpretation were discussed to achieve consensus. We then engaged in the following process for analysing the rest of the cartoons. The first author (DD) identified basic thematic ideas for all the cartoons, and the other two authors (SD and NS) equally divided the full set of cartoons, and individually analysed their half. Discrepancies were discussed among the members of the research team, and consensus was achieved. Refinement of the final themes was done by two authors (DD and SR).

\section{RESULTS}

Based on the keywords considered, 96 cartoons out of 127 were selected. Initial Cohen's Kappa showed 98.7\%, indicating perfect agreement (Watson \& Petrie, 2010). Nine of the 96 cartoons were excluded because they did not contain keywords or symbols related to COVID-19 and referred to settings other than Sri Lanka. The final collection included 87 cartoons (Figure 4). Of these, $28.74 \%$ (25) were PUNs, $36.78 \%$ (32) were SEMs while $34.48 \%$ (30) were classified as TOM. In theme identification, eight discrepancies were discussed, and consensus was achieved.

In total, 51 initial themes (Figure 5) were identified. Based on the similarities and common patterns, we combined these into 13 common themes (Table 1). 'COVID-19 as a global issue' provided the backdrop to the focus on the health, social, economic, political, and environmental impact in the Sri Lankan context.

\section{COVID-19 as a Global Issue}

In relation to broad aspects of 'COVID-19 as a global issue', we identified two common subthemes: (1) the power of a single virus to spread across international boundaries over a short period of time and (2) transmission of virus continues despite actions to reduce spread. As an example, a key message related to the nature of the pandemic at the global level by displaying the symbol of COVID-19 playing soccer with the globe, or toying with the world.

\section{Health aspects of COVID-19}

Three common themes were identified under the health aspects: (1) prevention is the priority; (2) a lack of knowledge about the virus leads to breaking health regulations, and (3) efforts to control virus outbreak where prevention has failed.

\section{Prevention is the priority}

Five subthemes are categorised under this common theme: (1) social distancing $(1 \mathrm{~m})$ to prevent the spread of COVID-19; (2) contravention of health regulations, including social distancing, leads to higher mortality; (3) inadequate personal protective equipment compromises the ability of healthcare workers to combat the COVID-19 virus outbreak; (4) consumers are required to use health precautions when they bring food into the home, and (5) people are encouraged to stay home to reduce spread of virus (igure 5 ).

\section{A lack of knowledge results in breaking health regulations}

This is a group of four subthemes: (1) the public should not believe myths about the virus, but should instead follow good health practices; (2) the SriLankan army is making a compassionate plea to curfew violators, in contrast to brutal methods used by military and police forces in other countries during the pandemic (3) incidents of breaking curfew are recorded and (4) nondisclosure of COVID-19 symptoms and contact information during the medical consultation is a threat to public health.

\section{Efforts to control virus outbreak}

Six subthemes were identified under this common theme: (1) health care workers use all possible precautions to control the virus, (2) controlling COVID-19 infection is everyone's responsibility, (3) continued effort to self-quarantine is necessary; (4) collective effort to beat the corona virus is required; 
(5) the poor and marginalized are facing added pressures caused by the virus; and (6) public servants such as the police are instrumental in ensuring the transmission of the virus is under control.

\section{Social impacts of COVID-19}

Related to the social impact of COVID-19, two common themes were identified: (1) pandemicrelated changes in socio-cultural practices and (2) effects of lockdown.

\section{Pandemic-related changes in socio-cultural practices}

This theme suggests disruption of major sporting events and national festivals in Sri Lanka (i.e., Sinhala and Hindu New Year).

\section{Effects of lockdown}

Effects of lockdown as a theme is represented by two subthemes: (1) the rise in domestic violence and (2) the closure of stores selling alcohol, resulting in lifestyle changes.

\section{Economic impact of COVID-19}

The economic impact of COVID-19 consists of three common subthemes: (1) the poor are impacted the most during the pandemic; (2) the global economy is crippled by the virus, and (3) the worsening pandemic has led to a black market for essential goods. The economic impact of COVID-19 consists of three common subthemes: (1) the poor are impacted the most during the pandemic; (2) the global economy is crippled by the virus, and ( 3 ) the worsening pandemic has led to a black market for essential goods.

Additional themes that have emerged relate to: (1) poverty and hunger are exacerbated by COVID-19; (2) different priorities and opportunities emerge for the rich and the poor during the COVID-19 crisis; (3) an increasing need to share wealth evenly among the rich and poor to effectively address the pandemic; (4) poverty and the high cost of living during the COVID19 crisis and (5) the need for the government to lower fuel prices to relieve pressure on marginalized individuals.

\section{Political impact of COVID-19}

IHTP, 1(2), 249-287, 2021 CC BY-NC-ND 4.0
Three common themes were identified related to the political impact of the pandemic: (1) apply health precautions during election activities; (2) seek strategies to hold the election and (3) other political involvements.

Health precautions applied during election-related activities

Two subthemes emerged under this common theme: (1) preventive measures such as social distancing during campaigns and (2) the need to postpone the election to prevent spread of the virus.

\section{Need to seek alternative strategies for election process}

Five subthemes were identified under this common theme such as (1) election barriers exist during the pandemic; (2) continued attempts to hold an election during the pandemic; (3) misinformation related to COVID -19 eradication is used as a campaign strategy by some candidates; (4) candidates use COVID-19 as a political tool to sway voters and (5) the need to maintain social distancing during an election.

\section{Additional themes related to politics}

Additional distinct themes related to politics are categorised under this common theme and include: (1) negative impact of politicians on society during the COVID-19 outbreak; (2) disunity among political parties concerning an election during the pandemic; (3) disproportional priority is placed on healthcare services (4) health care professionals face difficulties in controlling the spread of COVID-19 due to political and media influences; (5) due to the prevailing situation, the president cannot make a decision on the election, and (6) farming is encouraged during the pandemic.

\section{DISCUSSION}

Public awareness and social responsibility are essential to control the virus (Awadasseid, $\mathrm{Wu}$, Tanaka, \& Zhang, 2020). Güner, Hasanoğlu, and Aktaş (2020) highlighted self-quarantine, voluntary quarantine and mandatory quarantine as important 
COVID-19 prevention and control measures in the community. In keeping with this, many cartoons depict social distancing, avoiding crowds, and using facemasks and other personal protective equipment as preventive measures.

Yet, a lack of awareness about how to prevent virus spread has permeated the global community, and often leads to indifference, which may adversely affect attempts by the government and health care workers to keep the virus in check (Roy et al., 2020). A few cartoons in the current study aptly sum up how people violate quarantine rules. Information delivered through consistent messaging has been identified as capable of changing behaviour, including changing transmission-related behaviours of the public (Guest et al., 2020). Without such consistent messaging, public confusion is inevitable. Another set of cartoons in the current study addresses the importance of information sharing; particularly, disseminating accurate health information to enhance public awareness.

It is widely acknowledged that to control the explosive spread of COVID-19, a collaborative effort is paramount, involving all members of the health care network, decision-makers, and the public (SifuentesRodríguez \& Palacios-Reyes, 2020). In Sri Lanka, cartoonists have promoted a message that health care workers, armed forces, politicians and the general public must be actively involved in the process of controlling this pandemic. While everyone is engaging in prevention activities to some degree, a lack of personal protective equipment, especially for health care workers, is one of the most significant issues identified by the cartoons. Protecting the health and safety of health care workers is crucial in controlling the pandemic (Guest et al., 2020).

The public health strategies which have been taken to prevent the transmission of COVID-19 infection in Sri Lanka have led to significant changes in the social life of Sri Lankans. These strategies have affected Sri Lankans in ways that cannot be accurately measured in quantitative terms as they affect quality of life. The travel ban has minimized social contacts but has not been enough to contain the virus. Several cartoons capture the cancellation of Sinhalese and Hindu New Year Festival, one of the most important national festivals for Sri Lankans. Additionally, various social events such as scientific conferences, business meetings, sports events, fashion shows, and marriages have been cancelled or postponed due to the pandemic (Ali \& Alharbi, 2020). One cartoon depicts the anticipated cancellation of the 2020 Olympics in Tokyo due to COVID-19.

Moreover, cartoons depict the mental health impacts of the lockdown. For instance, domestic violence against women during this period has increased. The drastic changes in family structure have led to critical issues and tensions (Mazza, Marano, Lai, Janiri, \& Sani, 2020). Fears of increasing domestic violence, which includes physical, emotional, and sexual abuse, are prominent (M. Nicola et al., 2020). Public health measures should be taken to identify and minimise such occurrences.

The economic impact of COVID-19 on the country has been severe. The restriction in movement, nationwide curfews, travel bans, and border closures that were intended to help control the pandemic have caused tremendous hardship for low-income Sri Lankans, as depicted by several cartoons. Lockdowns disrupted the supply chain (Maria Nicola et al., 2020), resulting in inflated prices. Cartoonists showed that the financial collapse has led to increased concerns about shortages of essential food products. Meanwhile, the Sri Lankan Rupee depreciated against the US Dollar, significantly impacting the economic status of the country, as shown in several cartoons (Wu, 2011).

The political impact of COVID-19 on the country has been substantial. In the face of an increasing number of COVID-19 cases, the scheduled general election was postponed. Several cartoonists conceptualised this situation by depicting politicians working together to diminish the impact of the virus in the community. However, other cartoons featured politicians inserting political messages to motivate the public towards the election. Interestingly, several cartoons showed requisite health precautions being practiced by officials in election activities, which demonstrates a way to combine political messaging with important reinforcement of critical health care information as it relates to the pandemic. Maintaining social distancing, wearing face masks, and other personal protective equipment are shown in the 
cartoons to be effective in preventing the spread of infection during the election.

\section{LIMITATIONS}

This study has several limitations. The first is size. We selected 127 newspaper cartoons, which is a small number of cartoons as compared to the hundreds of newspaper cartoons produced on COVID-19 in Sri Lanka. As a result, other studies might draw different conclusions on the same topic. Another limitation is that newspaper cartoons might be interpreted differently by researchers from the cartoonists who created them.

\section{CONCLUSION}

In summary, this study is the first of its kind to explore newspaper cartoons representing the COVID-19 pandemic across several online newspapers in Sri Lanka. Cartoons have been used as an important medium to convey information on COVID-19, including prevention strategies guided by the $\mathrm{WHO}$, and the social, economic, political, and environmental effects of the pandemic on Sri Lanka. Our findings suggest that newspaper cartoons can be used as an effective means of disseminating information related to COVID-19. Public health workers and authorities can collaborate with popular cartoonists and media to design cartoons that can provide effective health messages. Future studies are warranted, with the collaborative involvement of cartoonists, on how to use cartoons even more productively.

\section{ACKNOWLEDGEMENT}

The authors wish to acknowledge the cartoonists and thank the editors from the following newspapers for providing permission to publish the cartoons in our manuscript: The Island, Ceylon Today, Adar, Daily Lankadeepa, Daily Mirror, Virakesari, and Mawbina.

\section{REFERENCES}

Ali, I., \& Alharbi, O. M. L. (2020). COVID-19: Disease, management, treatment, and social impact. Science of the Total Environment, 728, 138861. doi: 10.1016/j.scitotenv.2020.138861

IHTP, 1(2), 249-287, 2021 C Ryerson University OJS / PKP
Andrea, C. S. (2012). The influence of empathizing and systemizing on humor processing: Theory of Mind and humor. HUMOR, 25(1), 75-98. doi: https://doi.org/10.1515/humor-2012-0005

Awadasseid, A., Wu, Y., Tanaka, Y., \& Zhang, W. (2020). Initial success in the identification and management of the coronavirus disease 2019 (COVID-19) indicates human-to-human transmission in Wuhan, China. International Journal of Biological Science, 16(11), 18461860. doi:10.7150/ijbs.45018

Brandt, E. B., Beck, A. F., \& Mersha, T. B. (2020). Air pollution, racial disparities, and COVID-19 mortality. Journal of Allergy Clinical Immunology. doi: 10.1016/j.jaci.2020.04.035

Chakraborty, I., \& Maity, P. (2020). COVID-19 outbreak: Migration, effects on society, global environment, and prevention. The Science of the Total Environment, 728, 138882-138882.

doi: 10.1016/j.scitotenv.2020.138882

Gallagher, H. L., Happé, F., Brunswick, N., Fletcher, P. C., Frith, U., \& Frith, C. D. (2000). Reading the mind in cartoons and stories: an fMRI study of 'theory of mind' in verbal and nonverbal tasks. Neuropsychologia, 38(1), 11-21. doi: https://doi.org/10.1016/S00283932(99)00053-6

Gant, L. M., Shimshock, K., Allen-Meares, P., Smith, L., Miller, P., Hollingsworth, L. A., \& Shanks, T. (2009). Effects of Photovoice: Civic Engagement Among Older Youth in Urban Communities. Journal of Community Practice, 17(4), 358-376. doi:10.1080/10705420903300074

Ge, H., Wang, X., Yuan, X., Xiao, G., Wang, C., Deng, T., . . . Xiao, X. (2020). The epidemiology and clinical information about COVID-19. European Journal of Clinical Microbiology of Infectious Disease, 39(6), 1011-1019. doi:10.1007/s10096-020-03874-z

Green, M. J., \& Myers, K. R. (2010). Graphic medicine: use of comics in medical education and patient care. BMJ, 340, c863. doi:10.1136/bmj.c863

Guest, J. L., Del Rio, C., \& Sanchez, T. (2020). The Three Steps Needed to End the COVID-19 Pandemic: Bold Public Health Leadership, Rapid Innovations, and Courageous Political 
Will. JMIR Public Health Surveilancel, 6(2), e19043. doi:10.2196/19043

Güner, R., Hasanoğlu, I., \& Aktaş, F. (2020). COVID-19: Prevention and control measures in community. Turkish Journal of Medical Science, 50(Si-1), 571-577. doi:10.3906/sag2004-146

Houts, P. S., Doak, C. C., Doak, L. G., \& Loscalzo, M. J. (2006). The role of pictures in improving health communication: a review of research on attention, comprehension, recall, and adherence. Patient Education and Counselling, 61(2), 173-190. doi: 10.1016/j.pec.2005.05.004

Kawakib, A.-M., Muhammad, A. B., \& Fathi, M. (2016). A Semiotic Analysis of Political Cartoons in Jordan in Light of the Arab Spring. HUMOR, 29(4), 507-538. doi: https://doi.org/10.1515/humor-2016-0051

Kennedy, A., Rogers, A., Blickem, C., Daker-White, G., \& Bowen, R. (2014). Developing cartoons for long-term condition self-management information. BMC Health Services Research, 14(1), 60. doi:10.1186/1472-6963-14-60

Kwon, I. (2019). Conceptual mappings in political cartoons: A comparative study of the case of nuclear crises in US-North Korean relations. Journal of Pragmatics, 143, 10-27. doi:https://doi.org/10.1016/j.pragma.2019. 01.021

Leask, J. (2016). Media researchers must understand the audience too. European Journal of Public Health, 26(4), 534-535. doi:10.1093/eurpub/ckw003

Leask, J., Hooker, C., \& King, C. (2010). Media coverage of health issues and how to work more effectively with journalists: a qualitative study. BMC Public Health, 10(1), 535. doi:10.1186/1471-2458-10-535

Maryon-Davis, A. (2012). Using the mass media to promote health. InnovAiT, 5(12), 767-773. doi:10.1093/innovait/ins191

Mazza, M., Marano, G., Lai, C., Janiri, L., \& Sani, G. (2020). Danger in danger: Interpersonal violence during COVID-19 quarantine. Psychiatry Research, 289, 113046. doi: https://doi.org/10.1016/j.psychres.2020.11 3046

Nghiem, N., Leung, W., Cleghorn, C., Blakely, T., \& Wilson, N. (2019). Mass media promotion of a smartphone smoking cessation app: modelled health and cost-saving impacts. BMC Public Health, 19(1), 283. doi:10.1186/s12889-019-6605-8

Nicola, M., Alsafi, Z., Sohrabi, C., Kerwan, A., Al-Jabir, A., losifidis, C., . . Agha, R. (2020). The socioeconomic implications of the coronavirus pandemic (COVID-19): A review. International Journal of Surgery, 78, 185193. doi: 10.1016/j.ijsu.2020.04.018

Nicola, M., Alsafi, Z., Sohrabi, C., Kerwan, A., Al-Jabir, A., losifidis, C., . . Agha, R. (2020). The socioeconomic implications of the coronavirus pandemic (COVID-19): A review. International Journal of Surgery, 78, 185193. doi: https://doi.org/10.1016/j.ijsu.2020.04.018

Novak, D. R. (2010). Democratizing qualitative research: Photovoice and the study of human communication. Communication Methods and Measures, 4(4), 291-310. doi:10.1080/19312458.2010.527870

Nwabueze C, Igboeli C, \& U., U. (2017). Framing of cartoons on ebola virus disease

in selected Nigerian dailies: A content analysis. Journal of Health Communication, 2(1).

Perchtold-Stefan, C. M., Papousek, I., Rominger, C., Schertler, M., Weiss, E. M., \& Fink, A. (2020). Humor comprehension and creative cognition: Shared and distinct neurocognitive mechanisms as indicated by EEG alpha activity. Neuro Image, 213, 116695.

doi:https://doi.org/10.1016/j.neuroimage.2 020.116695

Roy, D., Tripathy, S., Kar, S. K., Sharma, N., Verma, S. K., \& Kaushal, V. (2020). Study of knowledge, attitude, anxiety \& perceived mental healthcare need in Indian population during COVID-19 pandemic. Asian Journal of Psychiatry, 51, 102083. doi:https://doi.org/10.1016/j.ajp.2020.1020 83

Sifuentes-Rodríguez, E., \& Palacios-Reyes, D. (2020). COVID-19: The outbreak caused by a new coronavirus. Boletín Médico del Hospital Infantil de México, 77(2), 47-53. doi:10.24875/bmhim.20000039

IHTP, 1(2), 249-287, 2021 CC BY-NC-ND 4.0

ISSN 2563-9269 
Tschacher, W., Genner, R., Bryjová, J., Schaller, E., \& Samson, A. C. (2015). Investigating vision in schizophrenia through responses to humorous stimuli. Schizophrenia Research: Cognition, 2(2), 84-88. doi:https://doi.org/10.1016/j.scog.2015.04. 007

Wakefield, M. A., Loken, B., \& Hornik, R. C. (2010). Use of mass media campaigns to change health behaviour. The Lancet, 376(9748), 12611271. doi:10.1016/S0140-6736(10)60809-4

Wang, C., Burris, M. A., \& Ping, X. Y. (1996). Chinese village women as visual anthropologists: a participatory approach to reaching policymakers. Social Science Medicine, 42(10), 1391-1400. doi:10.1016/02779536(95)00287-1

Watson, P. F., \& Petrie, A. (2010). Method agreement analysis: A review of correct methodology. Theriogenology, 73(9), 1167-1179. doi:https://doi.org/10.1016/j.theriogenolog y.2010.01.003

Wiid, R., Pitt, L., \& Mills, A. J. (2012). Every story tells a picture: Lessons from cartoons on corporate governance. Business Horizons, 55(6), 543-550. doi:https://doi.org/10.1016/j.bushor.2012.0 7.001

Wu, B. (2011). 4 - Consumption and economic law. In B. Wu (Ed.), Consumption and Management (pp. 61-97): Chandos Publishing.

Zhang, H.-W., Yu, J., Xu, H.-J., Lei, Y., Pu, Z.-H., Dai, W.C., . . . Li, D.-F. (2020). Coronavirus international public health emergencies: Implications for radiology management. Academic Radiology, 27(4), 463-467. doi:https://doi.org/10.1016/j.acra.2020.02. 003

Zhang, S. X., Liu, J., Afshar Jahanshahi, A., Nawaser, K., Yousefi, A., Li, J., \& Sun, S. (2020). At the height of the storm: Healthcare staff's health conditions and job satisfaction and their associated predictors during the epidemic peak of COVID-19. Brain Behavioural Immunology, 87, 144-146. doi:10.1016/j.bbi.2020.05.010 
Figure 1. Visual Puns

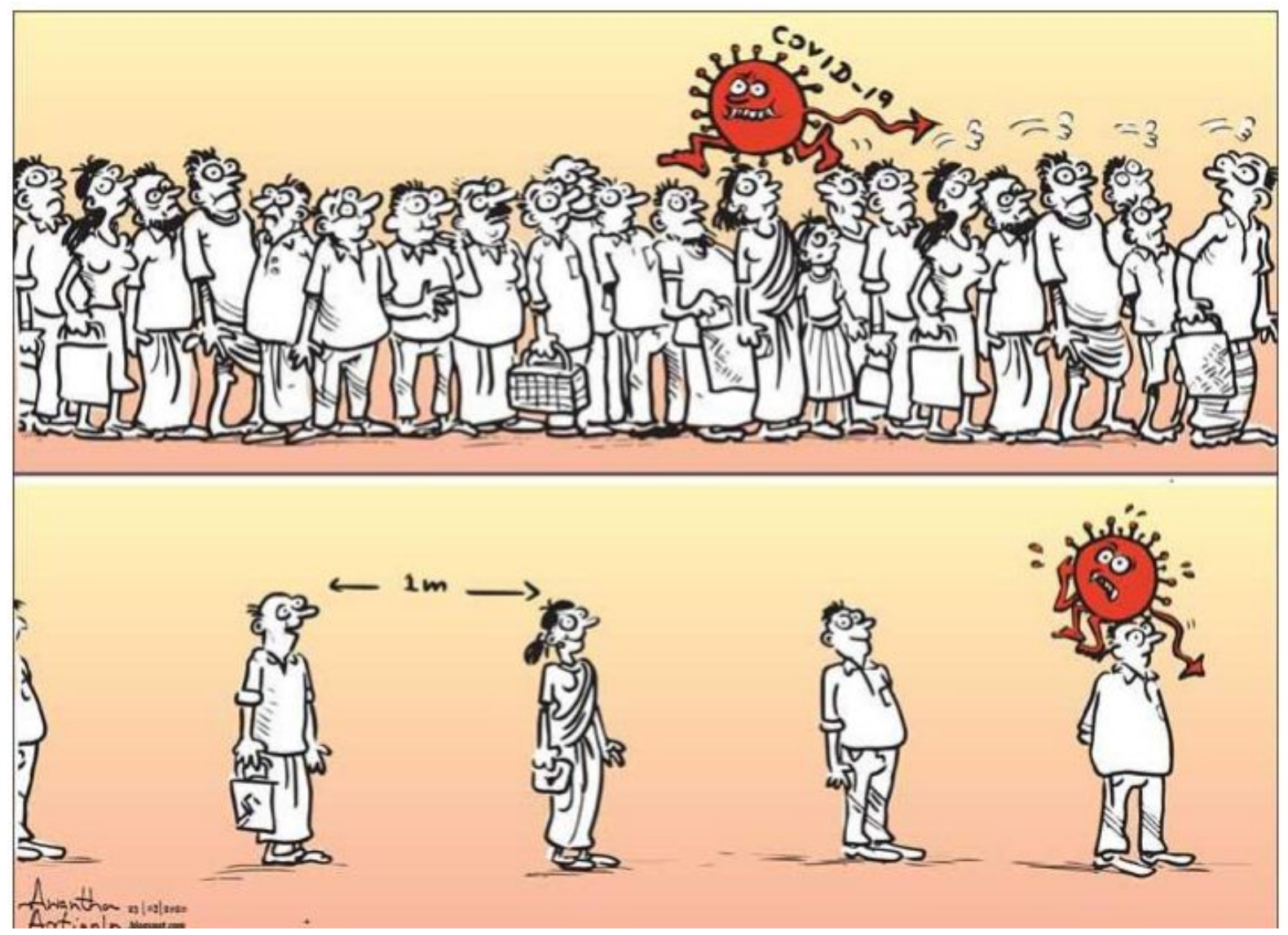


Figure 2. Semantic

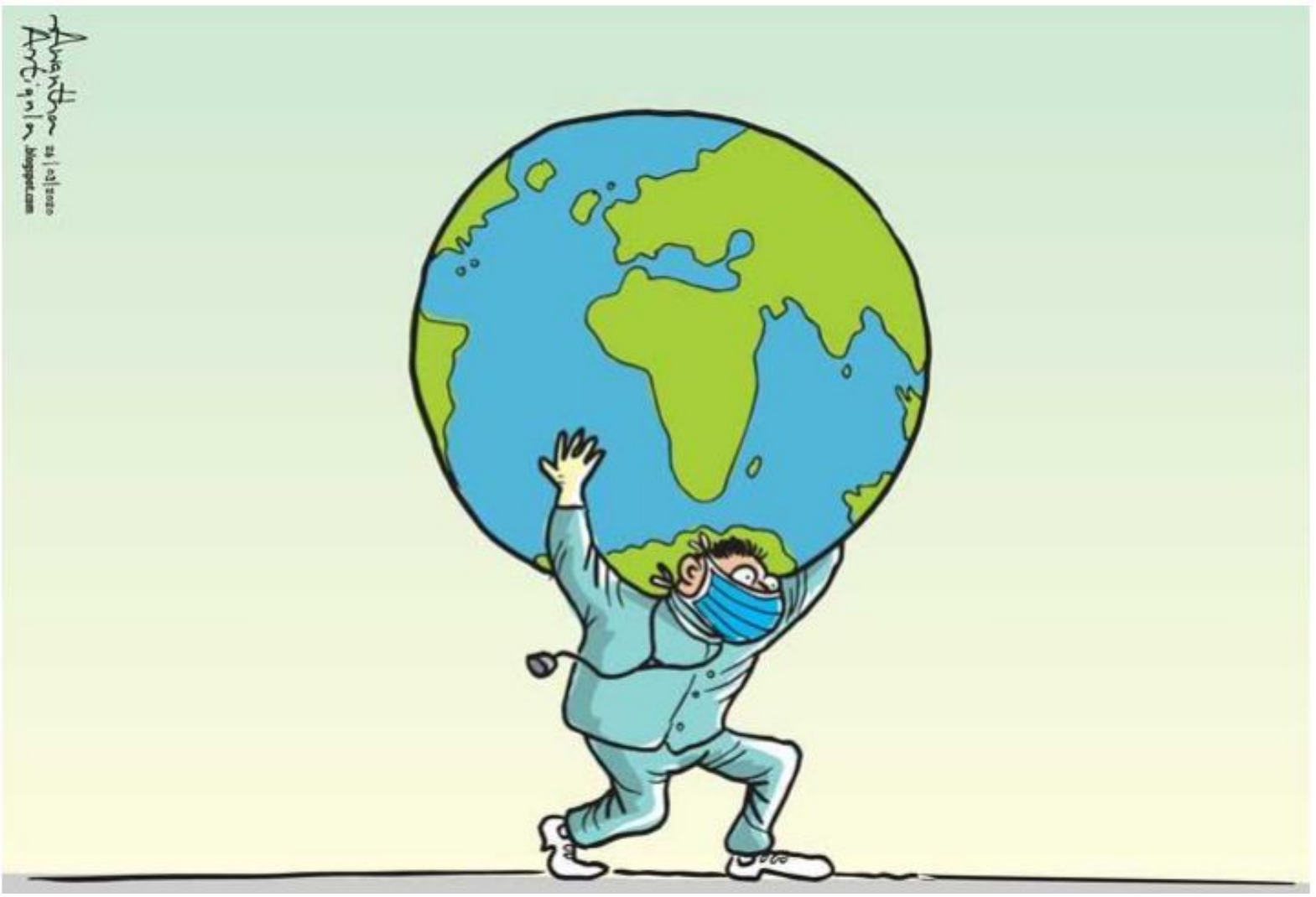


Figure 3. Theory of Mind

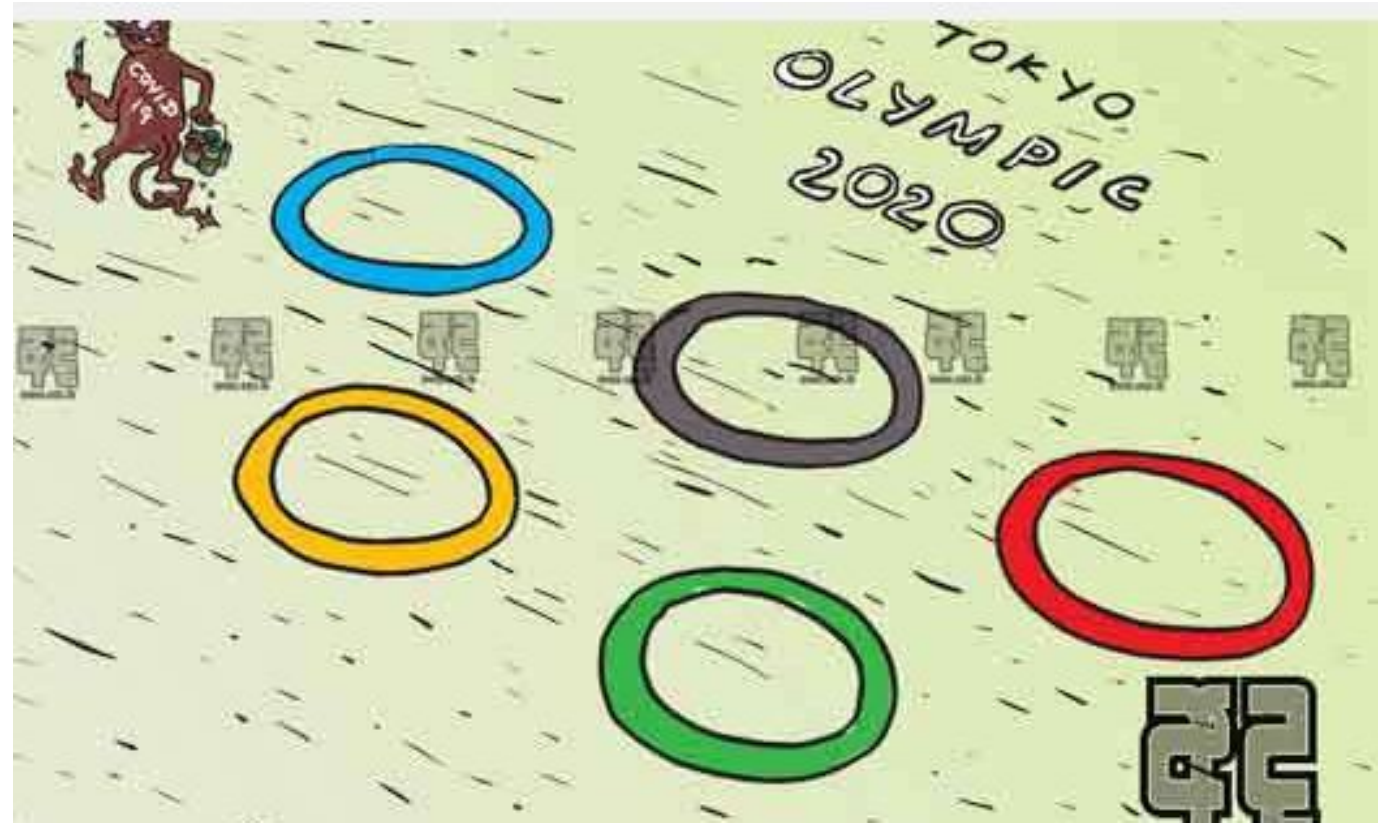


Figure 4. Study design flow chart

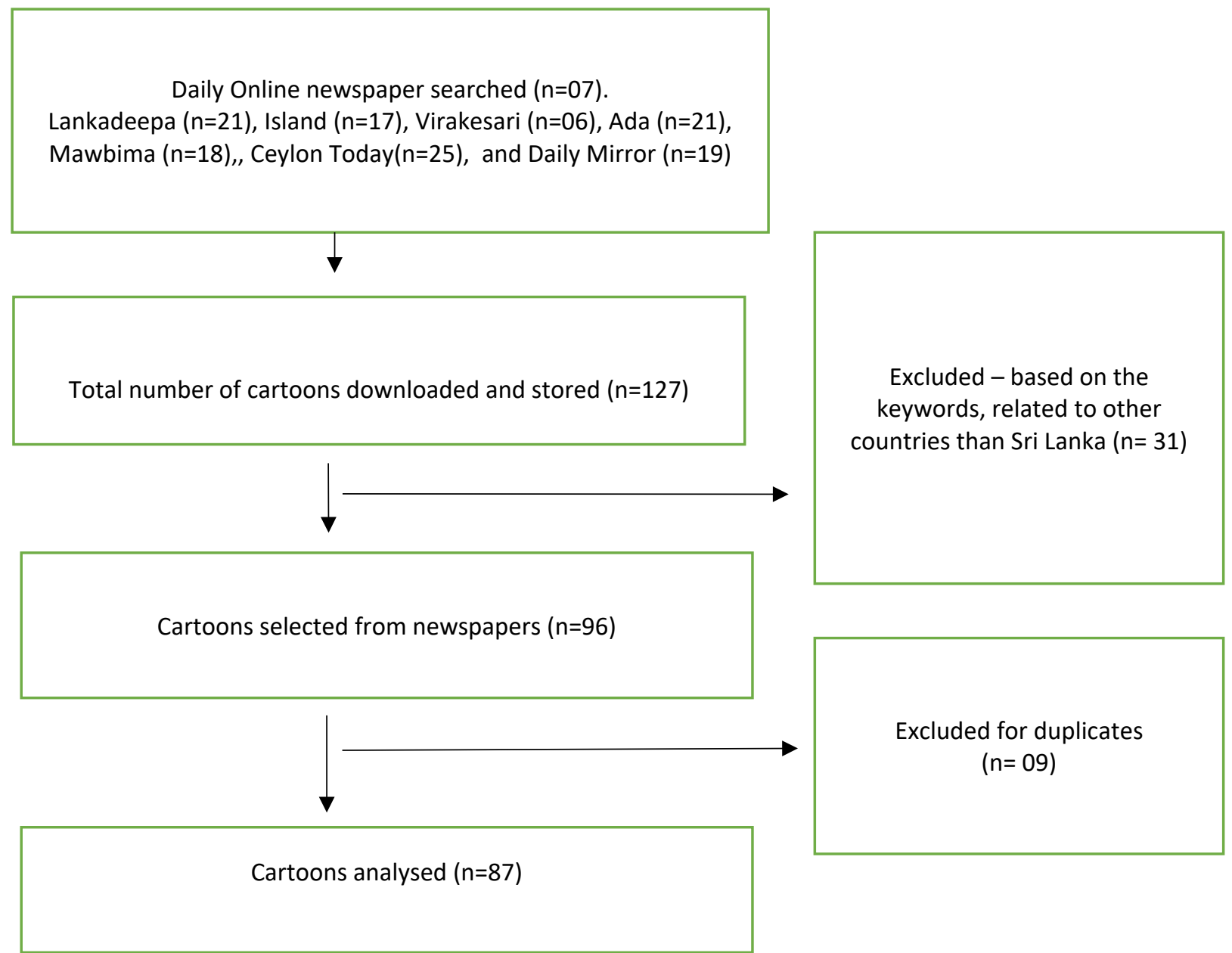


Figure 5. Examples for themes identified from the newspaper cartoons

Theme: Power of a single virus over the whole world

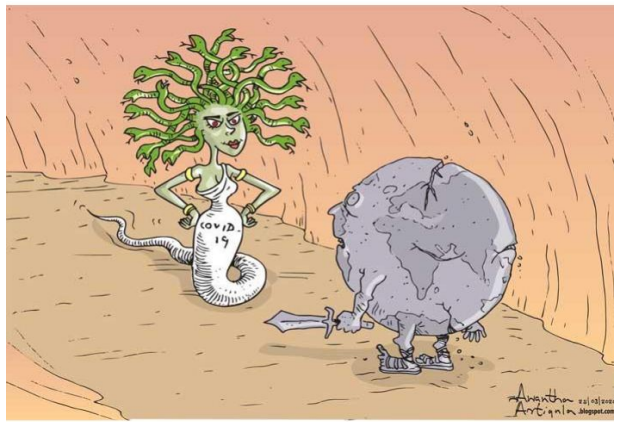

Cartoon No 01: 8 Ada, $25^{\text {th }}$ of March 2020

Theme: Coronavirus is engulfing the world in spite of resistance from the people

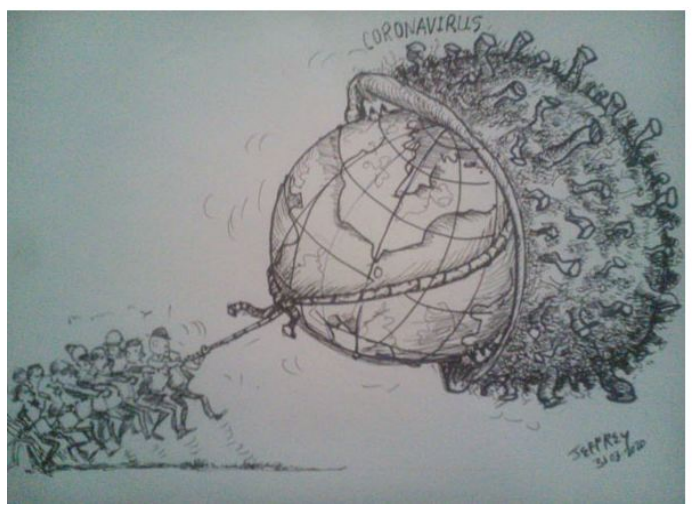

Cartoon No 02: 29 Island, 31 $1^{\text {st }}$ of March 2020 
Theme: COVID-19 plays with the world

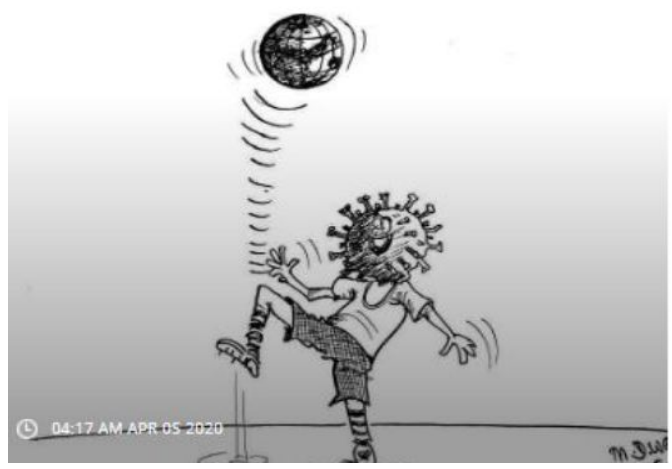

Cartoon No 03: Ceylon Today, 05 ${ }^{\text {th }}$ of April 2020

Theme: President trying to defeat the COVID-19 giant

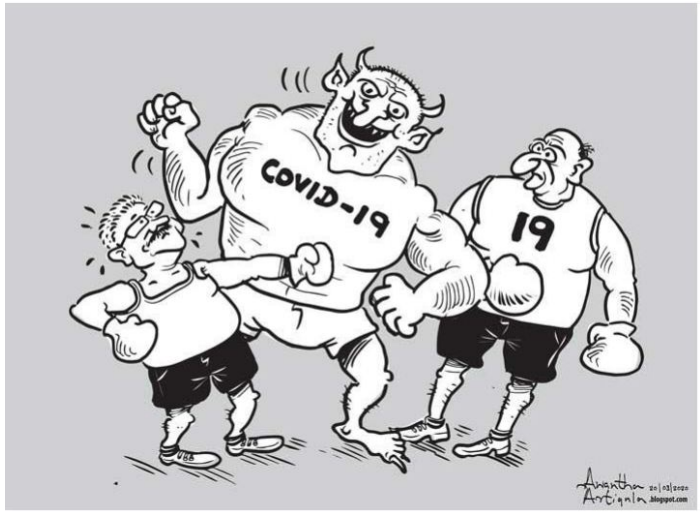

Cartoon No 04: Ada, 20 ${ }^{\text {th }}$ of March 2020 
Theme: The burden of the pandemic lies on the shoulders of the healthcare workers

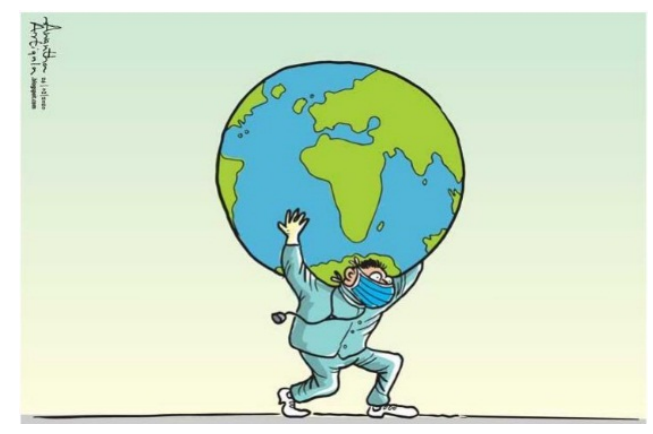

Cartoon No 05: Ada, $26^{\text {th }}$ of March 2020

Theme: Political instability due to the COVID-19

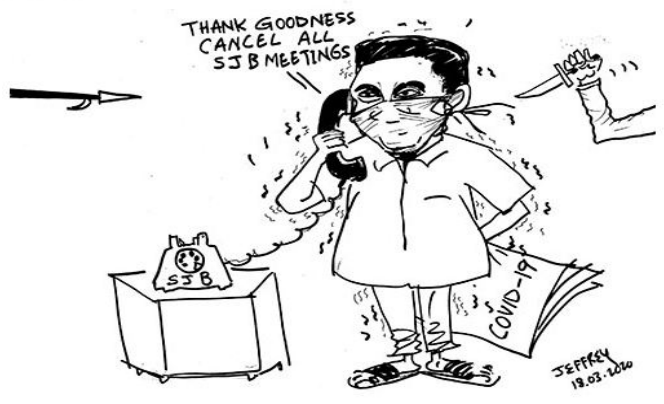

Cartoon No 06: Island, $17^{\text {th }}$ of March 2020 
Theme: World Health Organization (WHO) faces challenges due to the COVID-19 related to pressures of the United States (US)

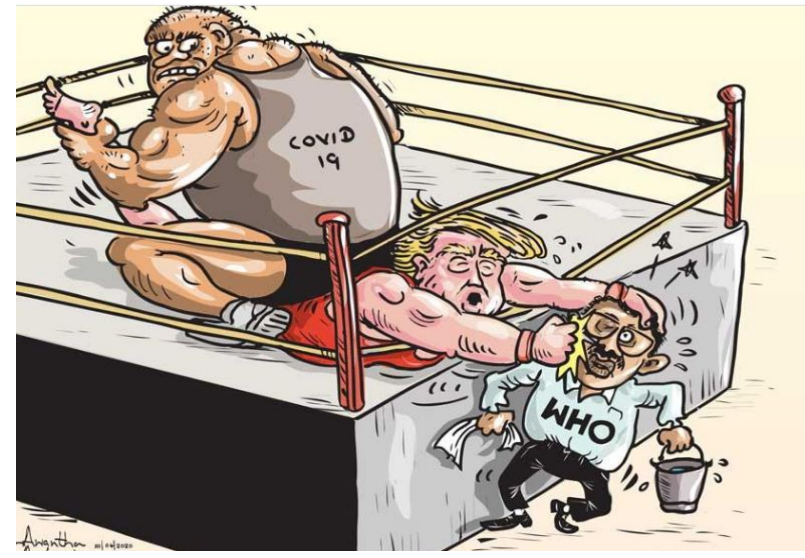

Cartoon No 07: Daily Mirror, $10^{\text {th }}$ of April 2020

Theme: COVID-19 creates national instability

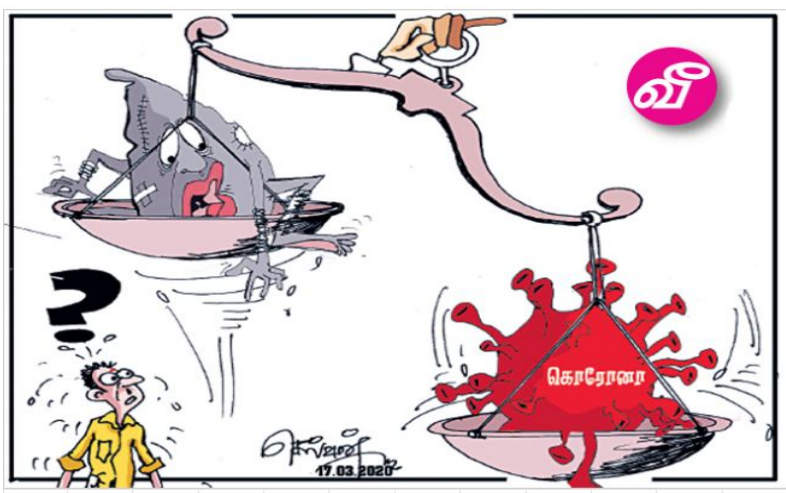

Cartoon No 08: Weerakesari, $17^{\text {th }}$ of March 2020 
Theme: Social distancing $(1 \mathrm{~m})$ to prevent the spread of Covid-19

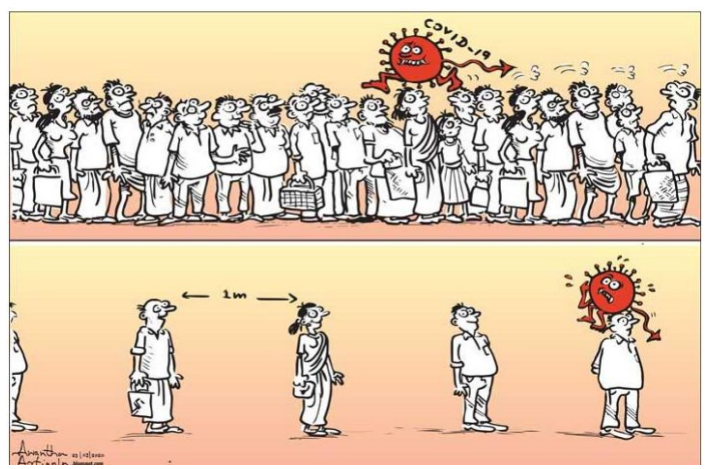

Cartoon No 09: Ada, $23^{\text {rd }}$ of March 2020

Theme: Breakdown of health regulations, including social distancing leads to higher mortality

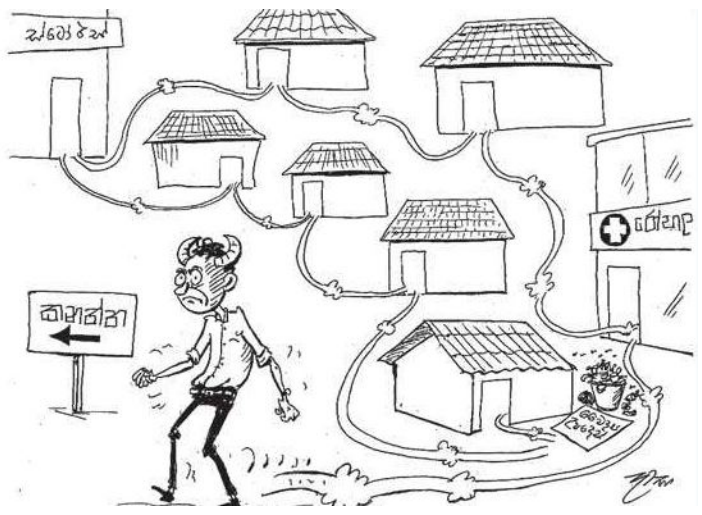

Cartoon No 10: Lankadeepa, $04^{\text {th }}$ of April 2020 
Theme: Inadequate personal protective equipment makes it hard for healthcare workers to combat the COVID-19 virus outbreak

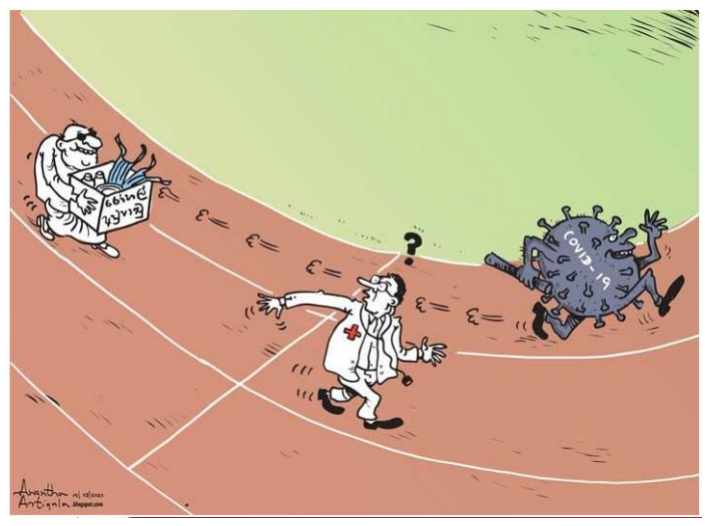

Cartoon No 11: Ada, $19^{\text {th }}$ of March 2020

Theme: Consumers must use health precautions when they bring food into the home

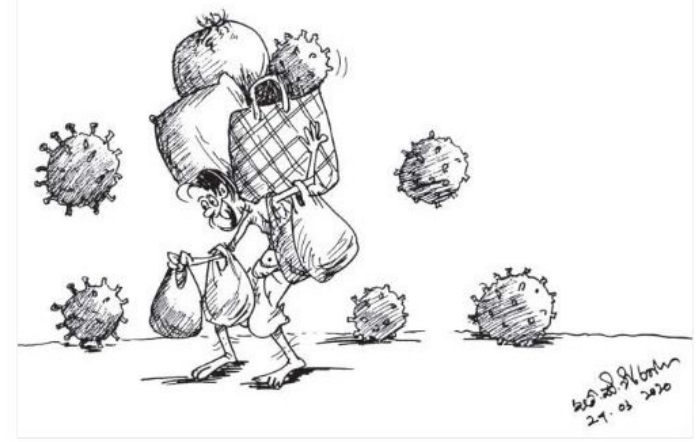

Cartoon No 12: Mawbima, 24 $4^{\text {th }}$ of March, 2020 
Theme: People are forced to stay home, if not they face the consequences of COVID-19

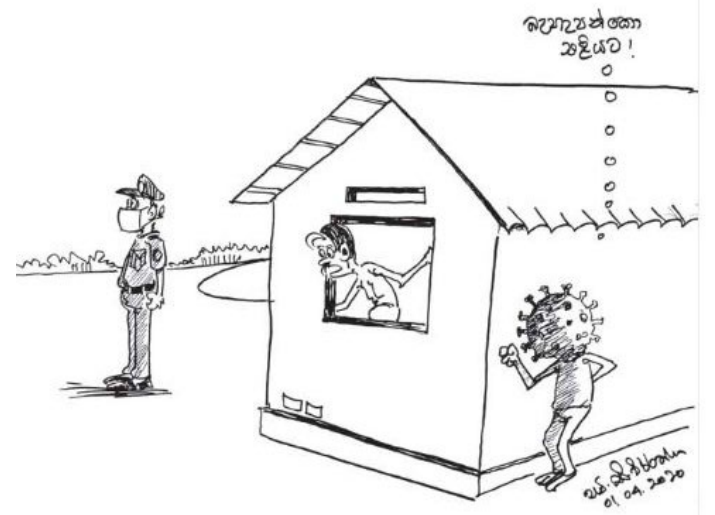

Cartoon No 13: Mawbima, $01^{\text {st }}$ April, 2020

Theme: Do not believe myths and follow good health habits

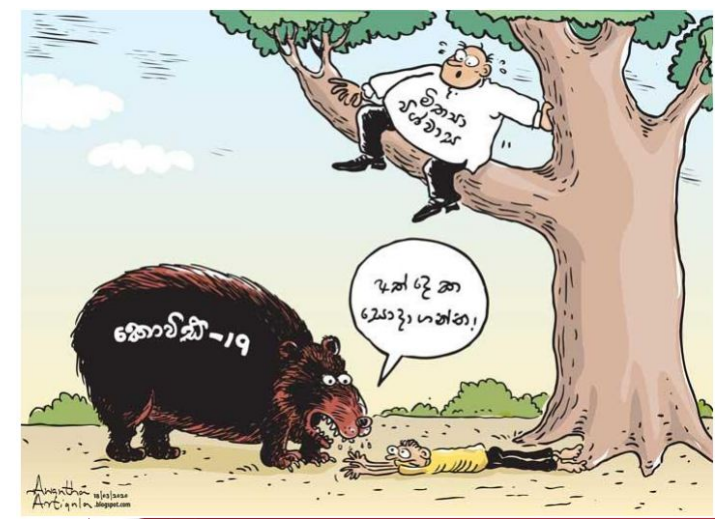

Cartoon No 14: Ada, $18^{\text {th }}$ of March, 2020 
Theme: Compassionate plea by the Sri-Lankan army towards curfew violators, in contrast to brutal methods used by forces of other countries during the pandemic

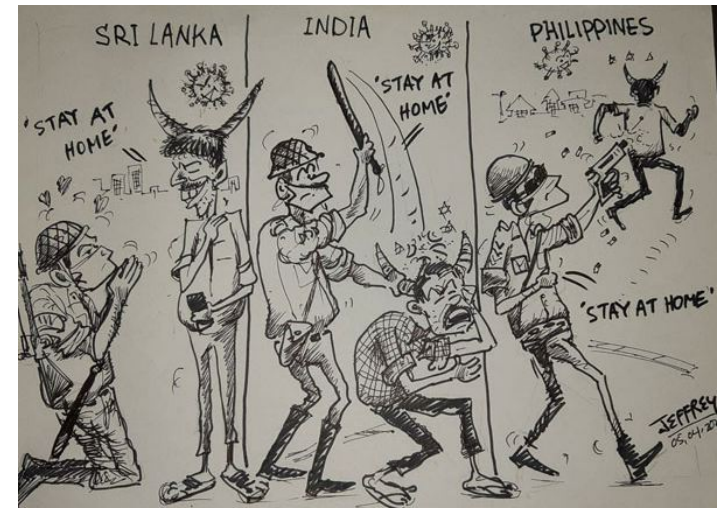

Cartoon No 15: Island, $06^{\text {th }}$ of April, 2020

Theme: Incidents of breaking curfew are recorded

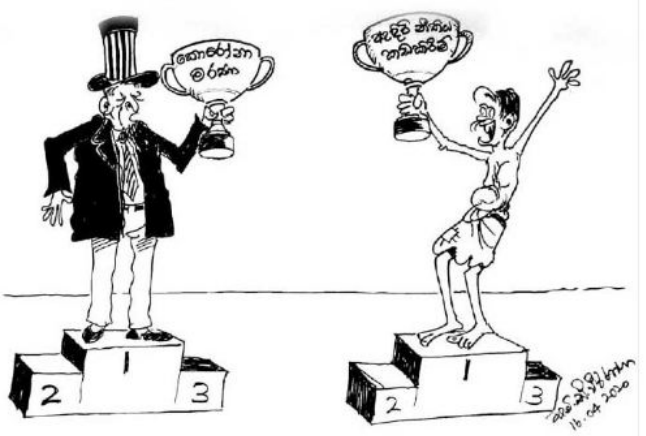

Cartoon No 16: Mawbima, 15 $5^{\text {th }}$ of April, 2020 
Theme: Nondisclosure of COVID- 19 symptoms and contact information during the medical consultation

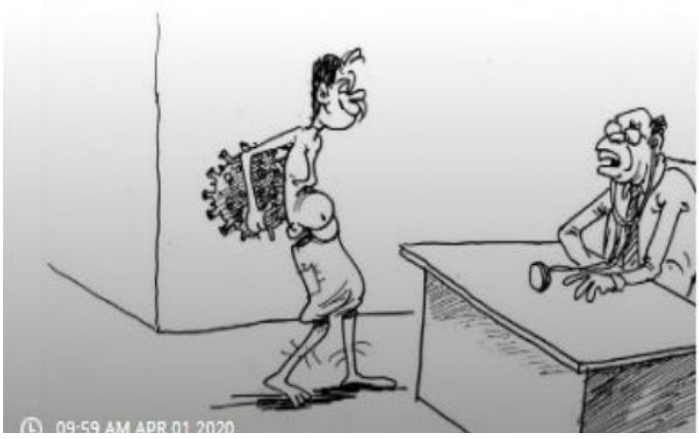

Cartoon No 17: Ceylon Today, 01 ${ }^{\text {st }}$ of April, 2020

Theme: Health care workers take every effort to control the virus

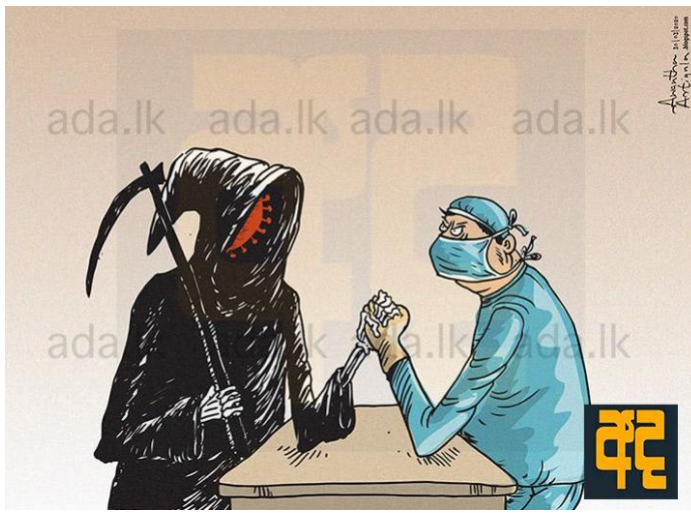

Cartoon No 18: Ada, 30 $30^{\text {th }}$ of March, 2020 
Theme: Controlling COVID-19 infection is everyone's responsibility

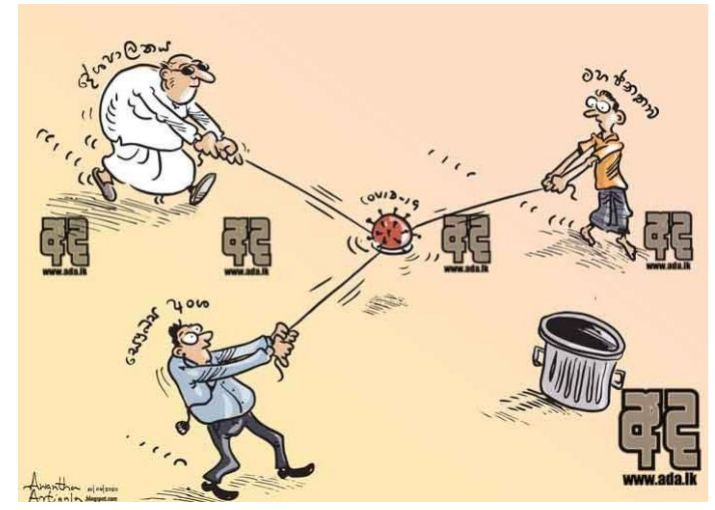

Cartoon No 19: Ada, $10^{\text {th }}$ of April, 2020

Theme: Continued effort of maintaining self quarantine by the whole world in the fight against corona virus

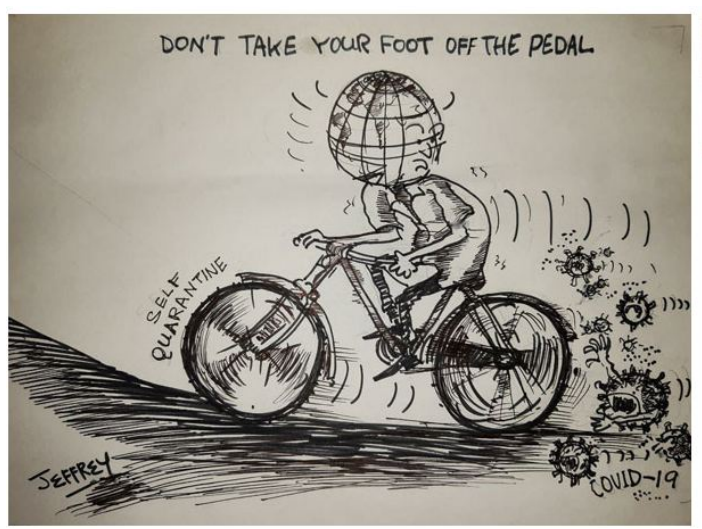

Cartoon No 20: Island, $02^{\text {nd }}$ of April, 2020 
Theme: Collective effort to beat the corona virus

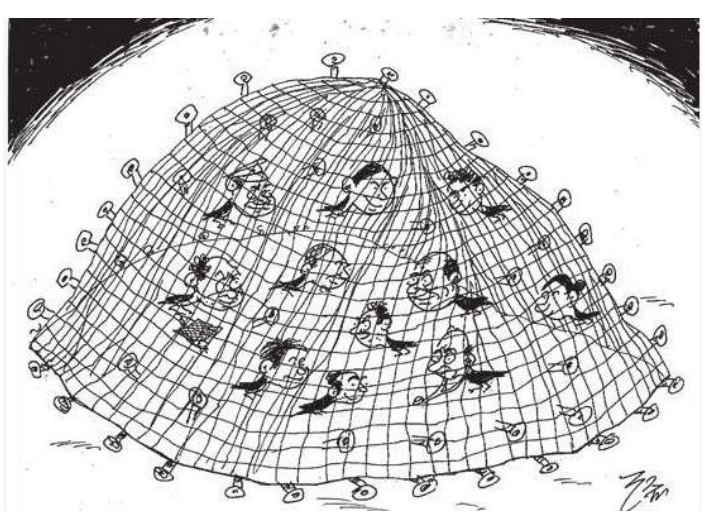

Cartoon No 21: Lankadeepa, $28^{\text {th }}$ of March, 2020

Theme: People who are already dealing with poverty and unemployment are trying to prevent the spread of COVID-19

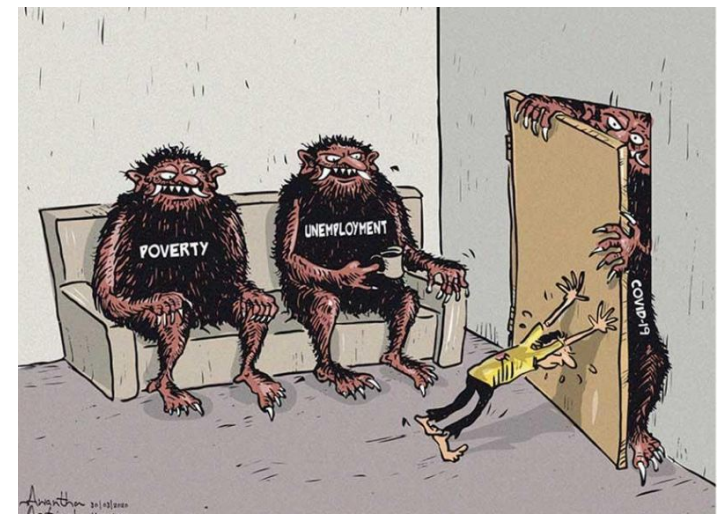

Cartoon No 22: Daily Mirror, $30^{\text {th }}$ of march, 2020 
Theme: Sri Lankan police play a major role in preventing the public getting infected by COVID- 19

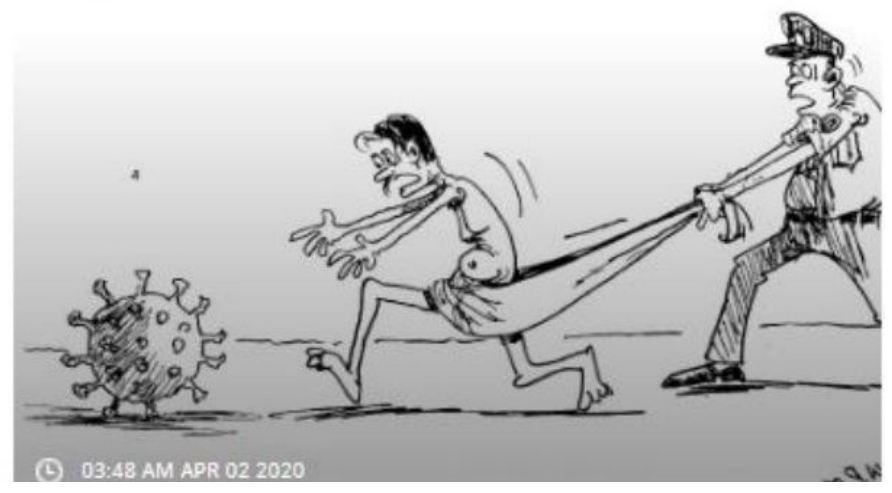

Cartoon No 23: Ceylon Today, $02^{\text {nd }}$ of March, 2020

Theme: COVID-19 virus disrupts major sports events

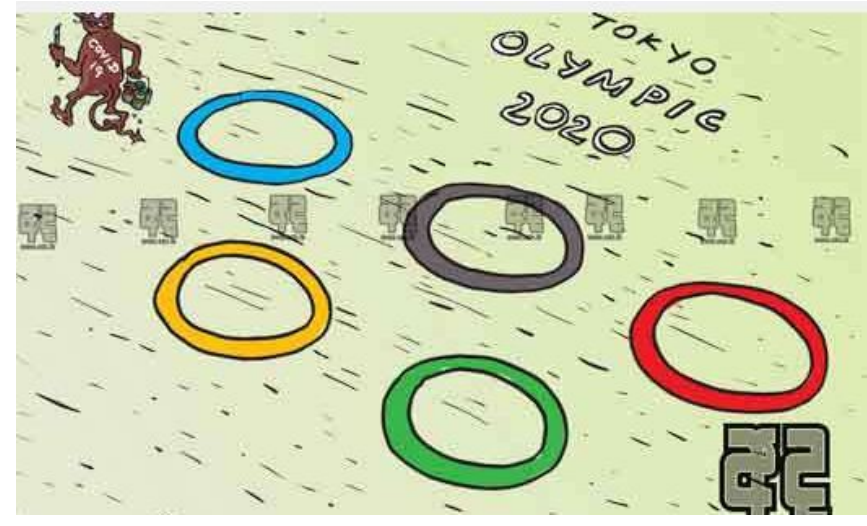

Cartoon No 24: Ada, 08thof April, 2020 
Theme: Impact of corona virus pandemic on National Festivals in Sri Lanka (i.e, Sinhala and Hindu New Year)

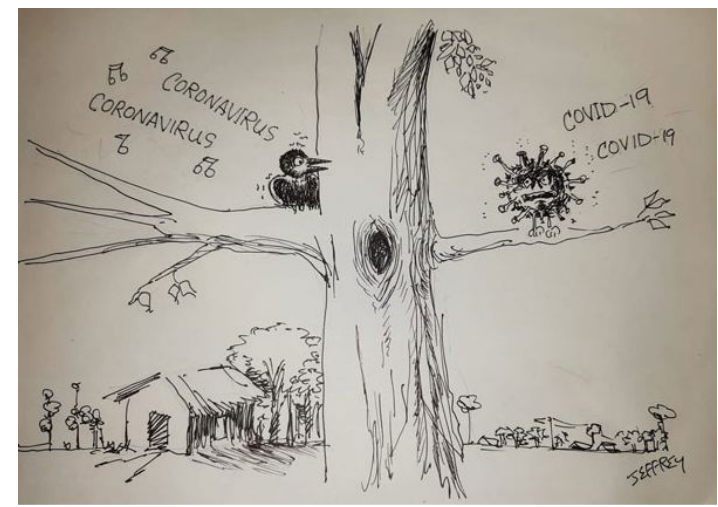

Cartoon No 25: Island, $07^{\text {th }}$ of April, 2020

Theme: Domestic violence during lockdown

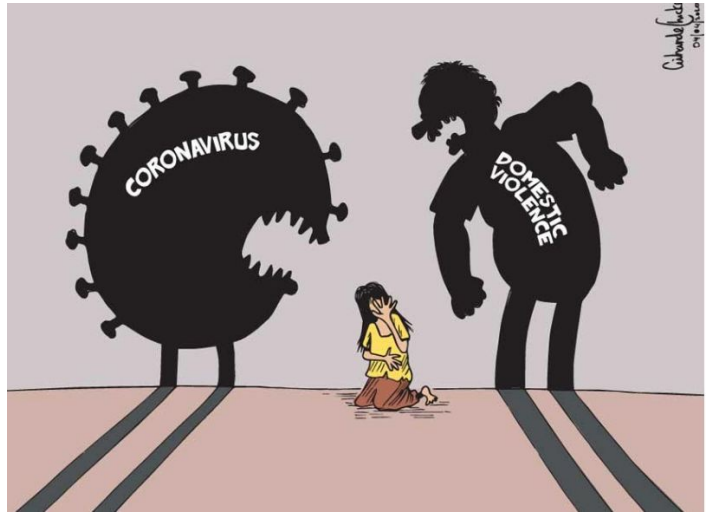

Cartoon No 26: Daily Mirror, $04^{\text {th }}$ of April, 2020 
Theme: Closure of wine stores during the pandemic and lifestyle changes during the pandemic

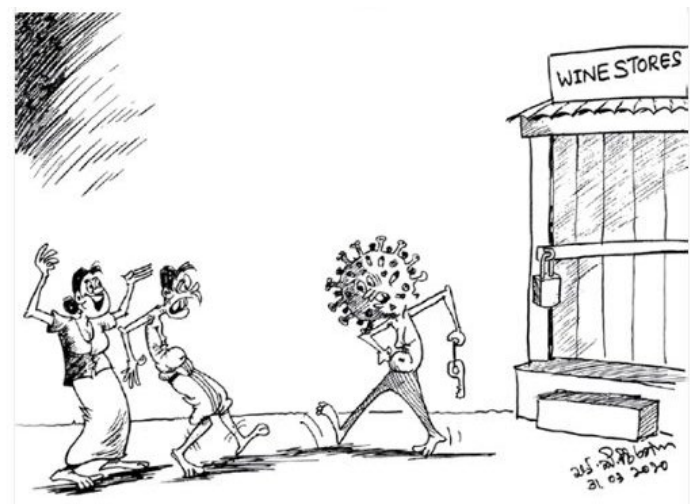

Cartoon No 27: Mawbima, 31 $1^{\text {st }}$ of March, 2020

Theme: Poverty, hunger and COVID-19

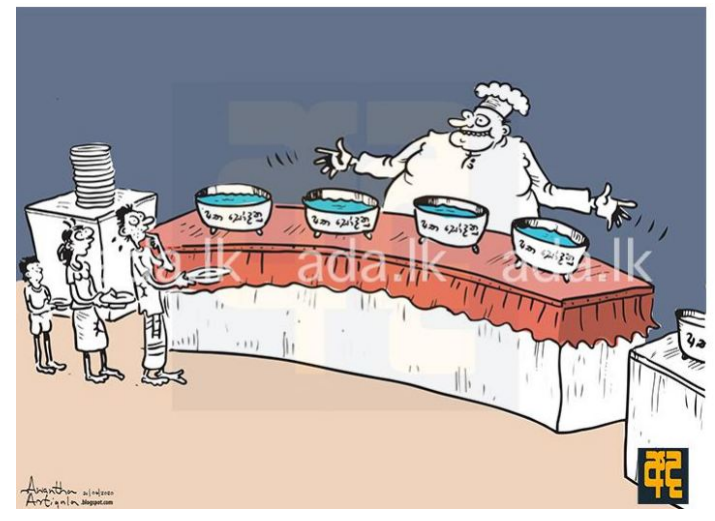

Cartoon No 28: Ada, $01^{\text {st }}$ of April, 2020 
Theme: Double standard for rich and the poor during the COVID-19 crisis

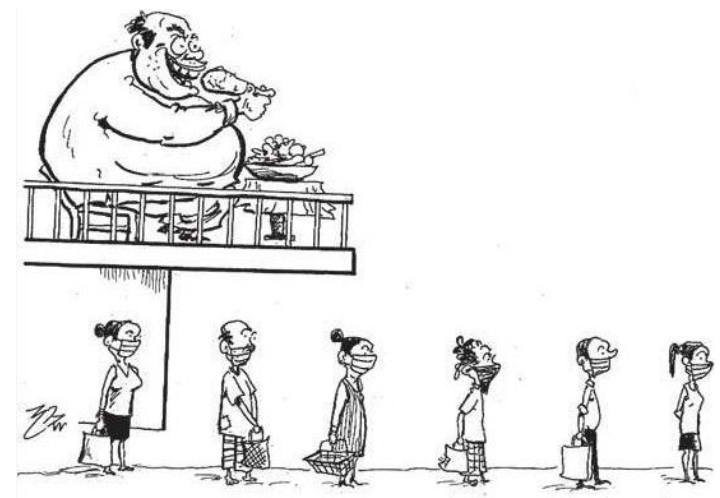

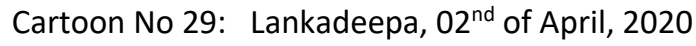

Theme: Unless we learn to share the wealth among the rich and poor and we will never be able to beat COVID-19

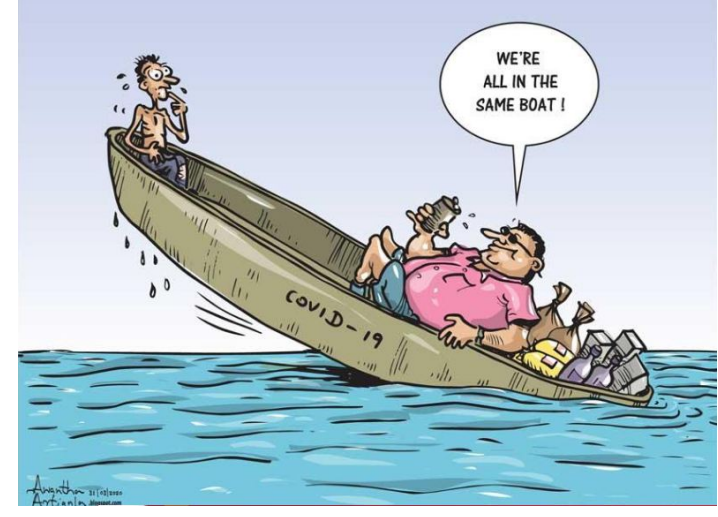

Cartoon No 30: Daily Mirror, $31^{\text {st }}$ March, 2020 
Theme: Poverty and high cost of living during the COVID-19 crisis

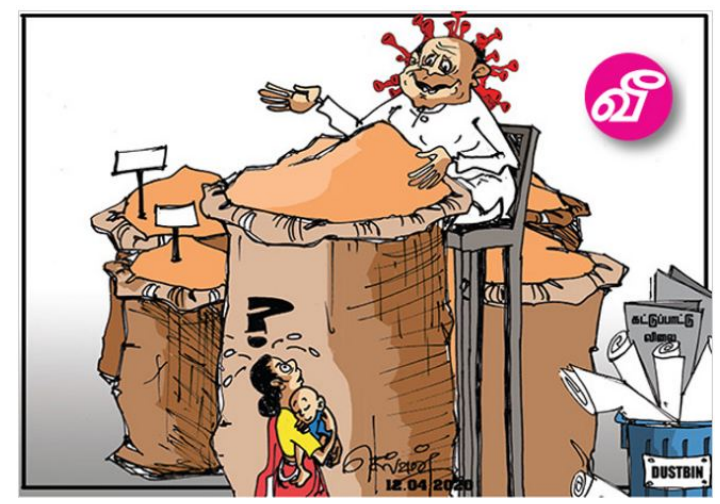

Cartoon No 31: Weerakesari, $12^{\text {th }}$ of April, 2020

Theme: Government refuse to lower fuel prices during a pandemic

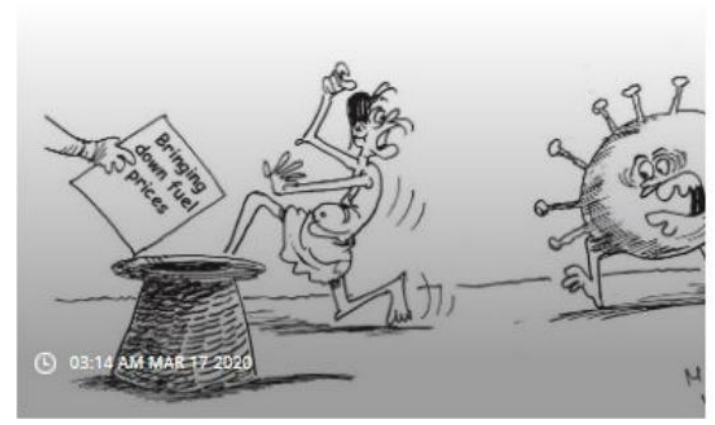

Cartoon No 32: Ceylon Today, $17^{\text {th }}$ of March, 2020 
Theme: Negative impact of COVID-19 on the Sri-Lankan economy (the devaluation of the Sri Lankan rupee against the US dollar)

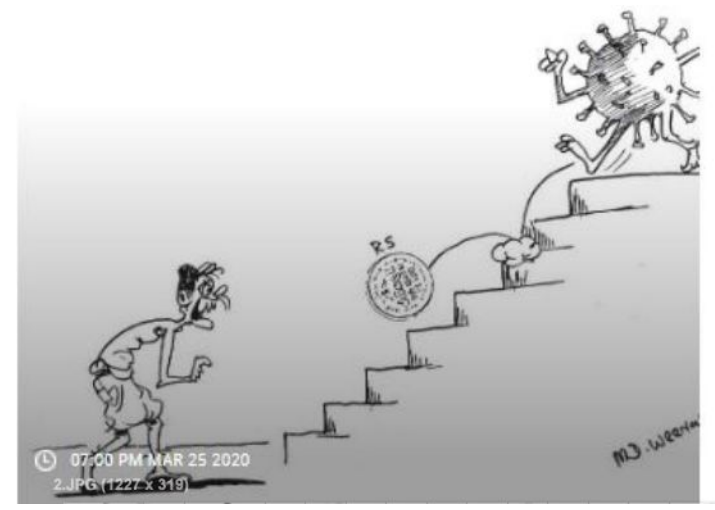

Cartoon No 33: Ceylon Today, $25^{\text {th }}$ of March, 2020

Theme: Corona virus threatens the poorest.

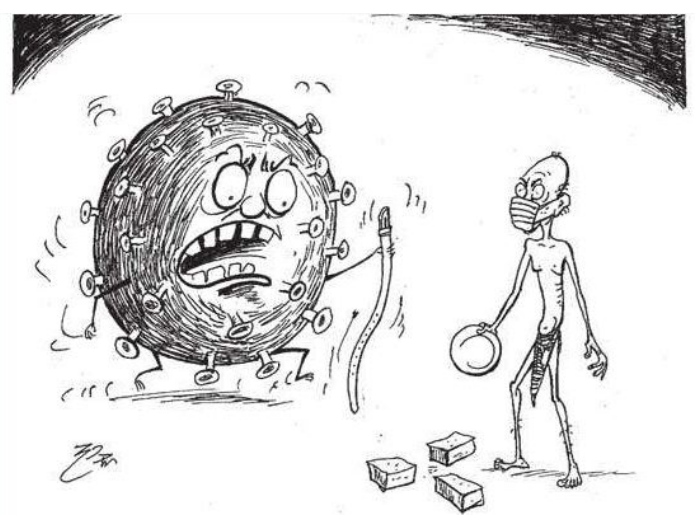

Cartoon No 34: Lankadeepa, $03^{\text {rd }}$ of April, 2020 
Theme: Hardships for consumers during COVID-19 pandemic by black market activity

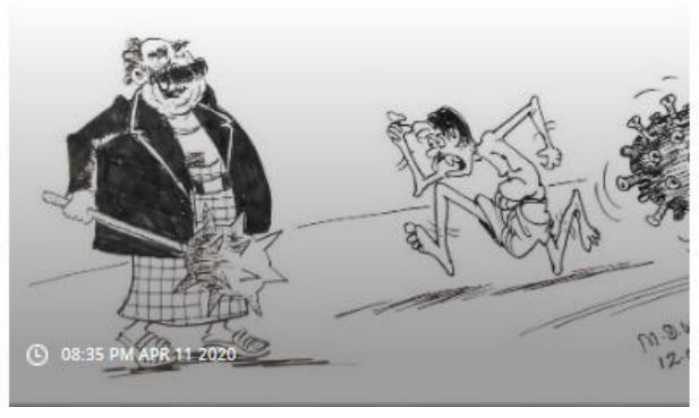

Cartoon No 35: Ceylon Today, $11^{\text {th }}$ of April, 2020

Theme: Poor farmers are cheated by mediators

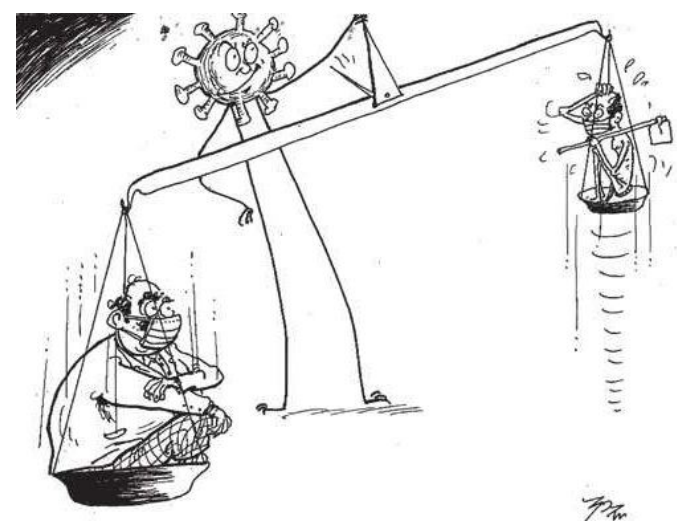

Cartoon No 36: Lankadeepa, $01^{\text {st }}$ of April, 2020 
Theme: Preventive measures such as social distance during nominations

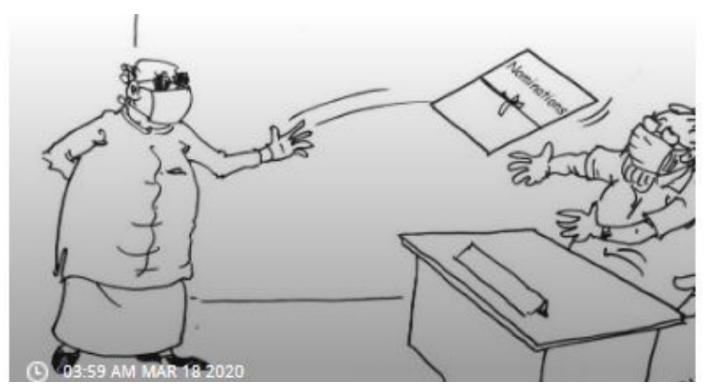

Cartoon No 37: Ceylon Today, $18^{\text {th }}$ of March, 2020

Theme: Election commission tries to postpone the election

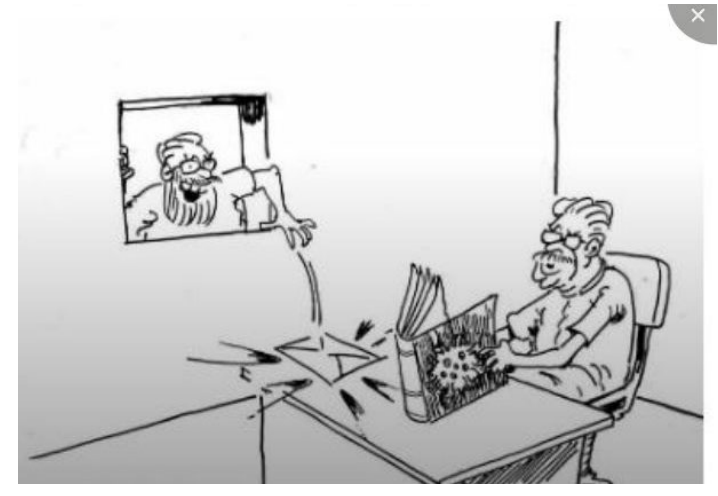

Cartoon No 38: Ceylon Today, $11^{\text {th }}$ of April, 2020 
Theme: Barriers to hold the election due to rapid transmission of COVID-19 infection

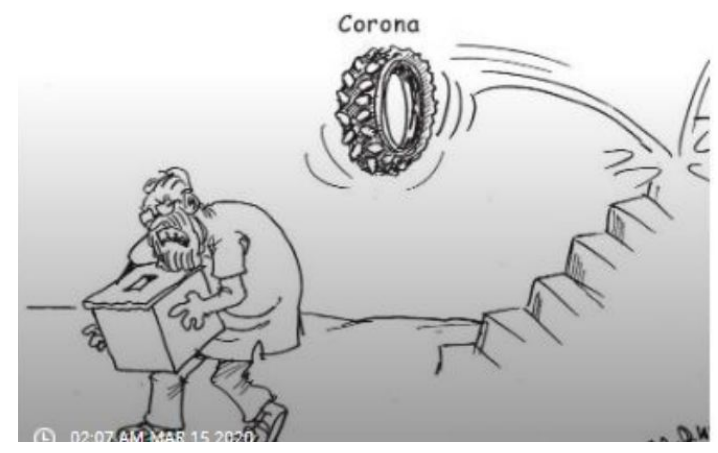

Cartoon No 39: Ceylon Today, $15^{\text {th }}$ of March, 2020

Theme: Attempts to have an election during the pandemic

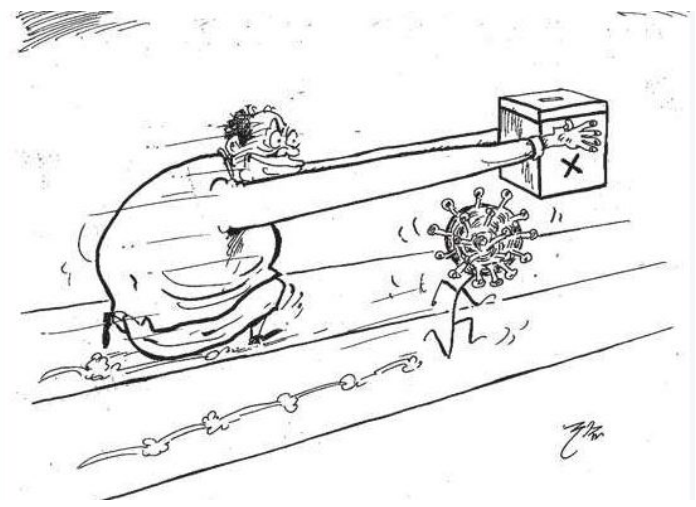

Cartoon No 40: Lankadeepa, $19^{\text {th }}$ of March, 2020 
Theme: Cunning politicians woo the people's vote by showing a COVID -19 eradication placard

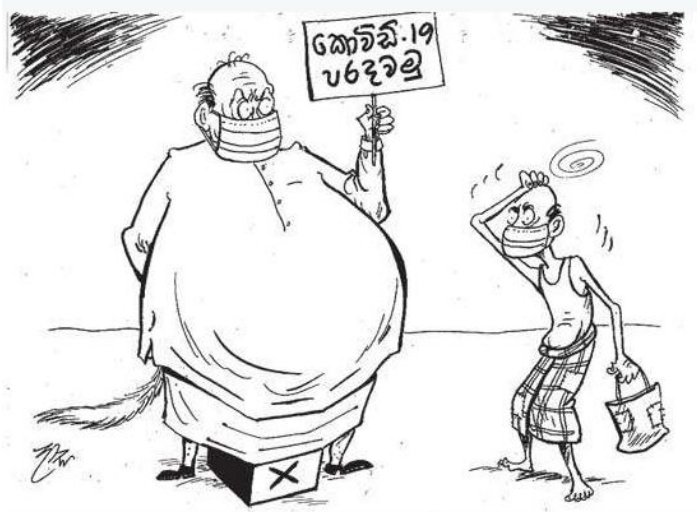

Cartoon No 41: Lankadeepa, $24^{\text {th }}$ of March, 2020

Theme: Candidates of all political parties resemble COVID-19 in the eyes of the voter

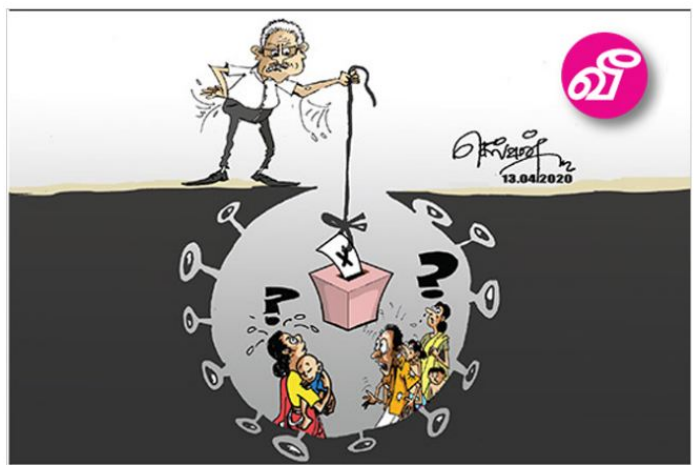

Cartoon No 42: Weerakesari, $13^{\text {th }}$ of April, 2020 
Theme: People try to maintain social distance while politicians want a 2020 election

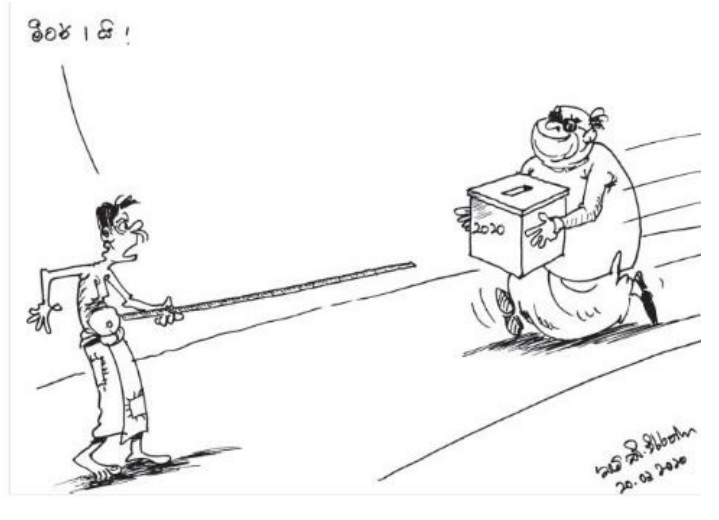

Cartoon No 43: Mawbima, 20 ${ }^{\text {th }}$ of March, 2020

Theme: Negative impact of politicians towards society during the covid-19 outbreak

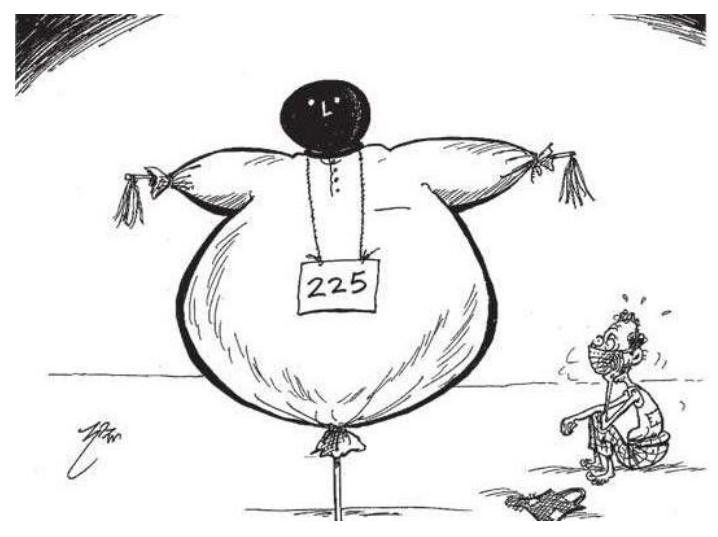

Cartoon No 44: Lankaadepa, $11^{\text {th }}$ of April, 2020 
Theme: Disunity among political parties on the election during the pandemic

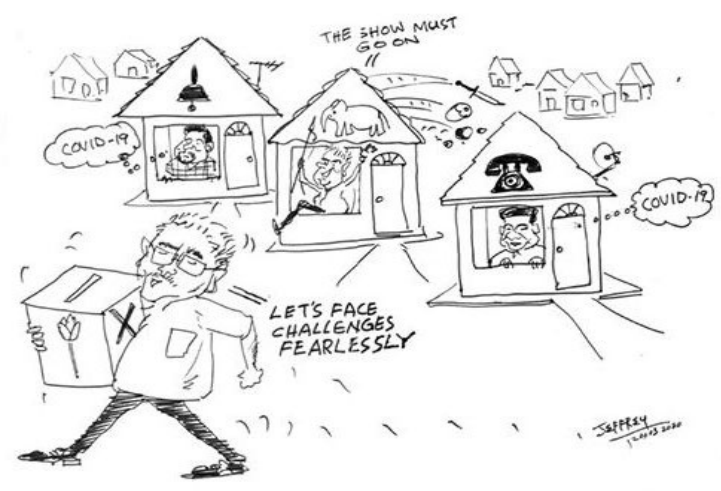

Cartoon No 45: Island, $19^{\text {th }}$ of March, 2020

Theme: Some politicians give less priority for health service

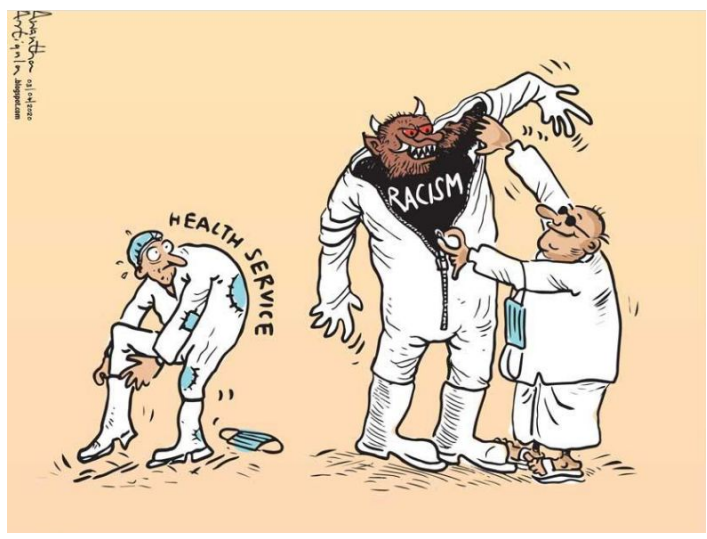

Cartoon No 46: Daily Mirror, $03^{\text {rd }}$ of April, 2020 
Theme: Health care professionals face difficulties in controlling the spread of COVID-19 due to political and media influences

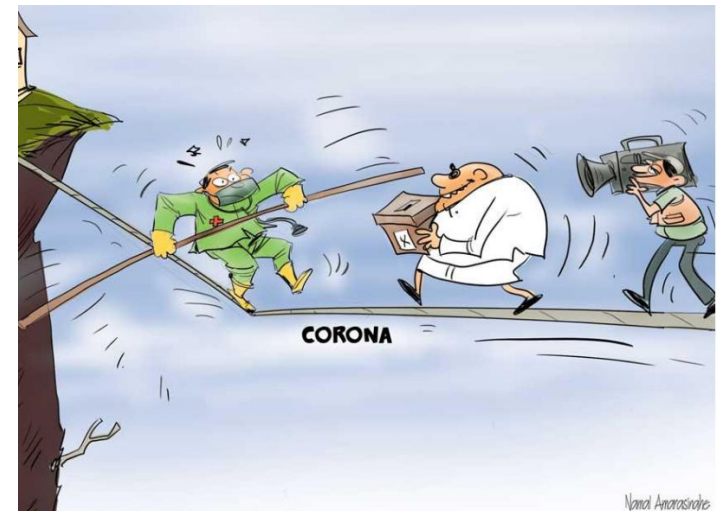

Cartoon No 47: Daily Mirror, $09^{\text {th }}$ of April, 2020

Theme: Due to the prevailing situation, the president cannot make a decision on the election

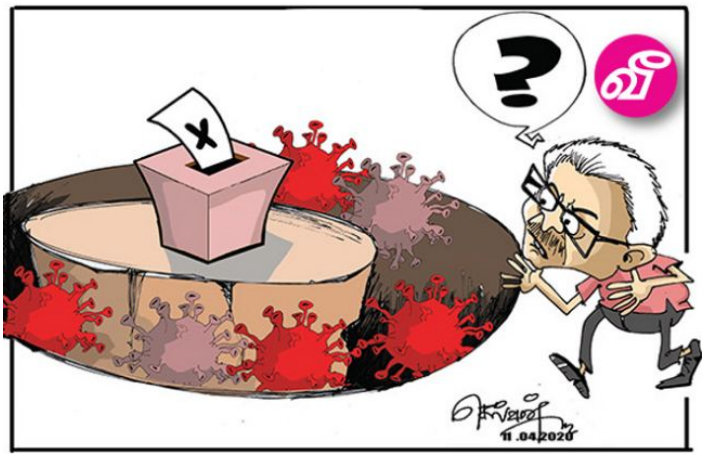

Cartoon No 48: Weerakesai, $11^{\text {th }}$ of April, 2020 
Theme: Prime Minister promotes farming during the pandemic

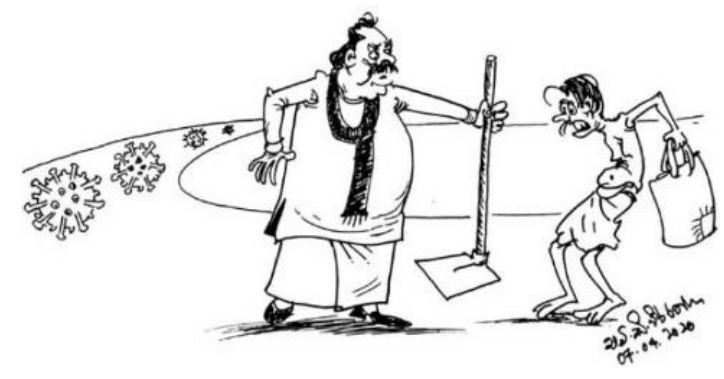

Cartoon No 49: Mawbima, $07^{\text {th }}$ of April, 2020

Theme: People face continuous disasters (Last year terrorist attack and this year crisis from COVID outbreak

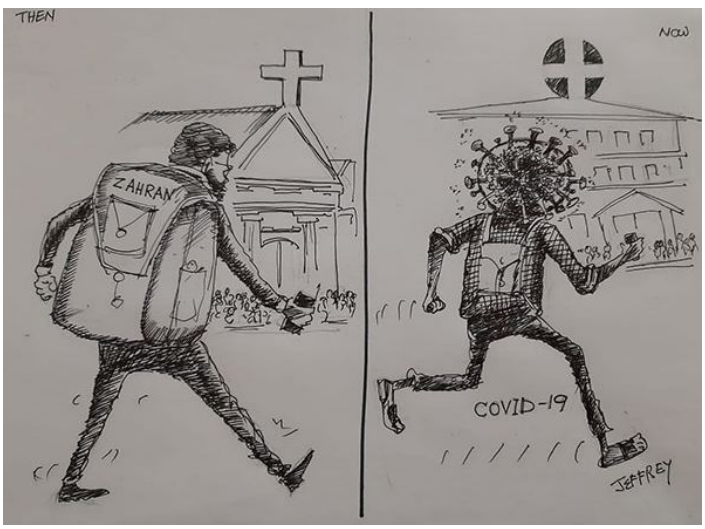

Cartoon No 50: Island, $09^{\text {th }}$ of April, 2020 
Theme: Environment threats people

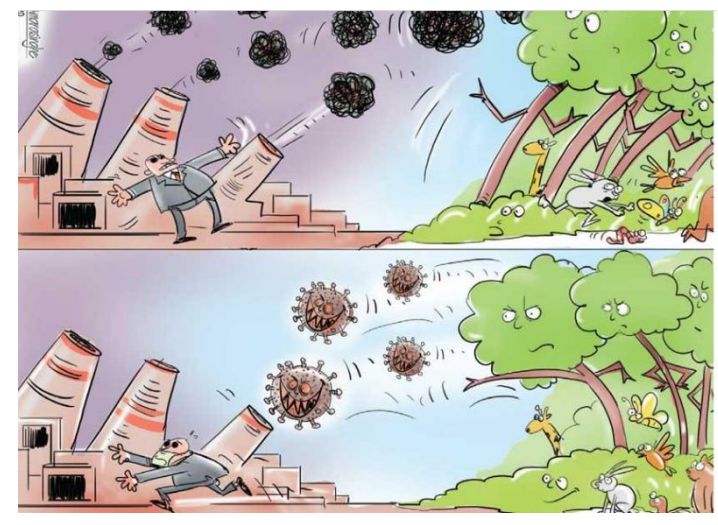

Cartoon No 51: Daily Mirror, 27 $7^{\text {th }}$ of March, 2020 
International Health Trends and Perspectives

Table 1. Major themes and sub-themes identified from cartoons

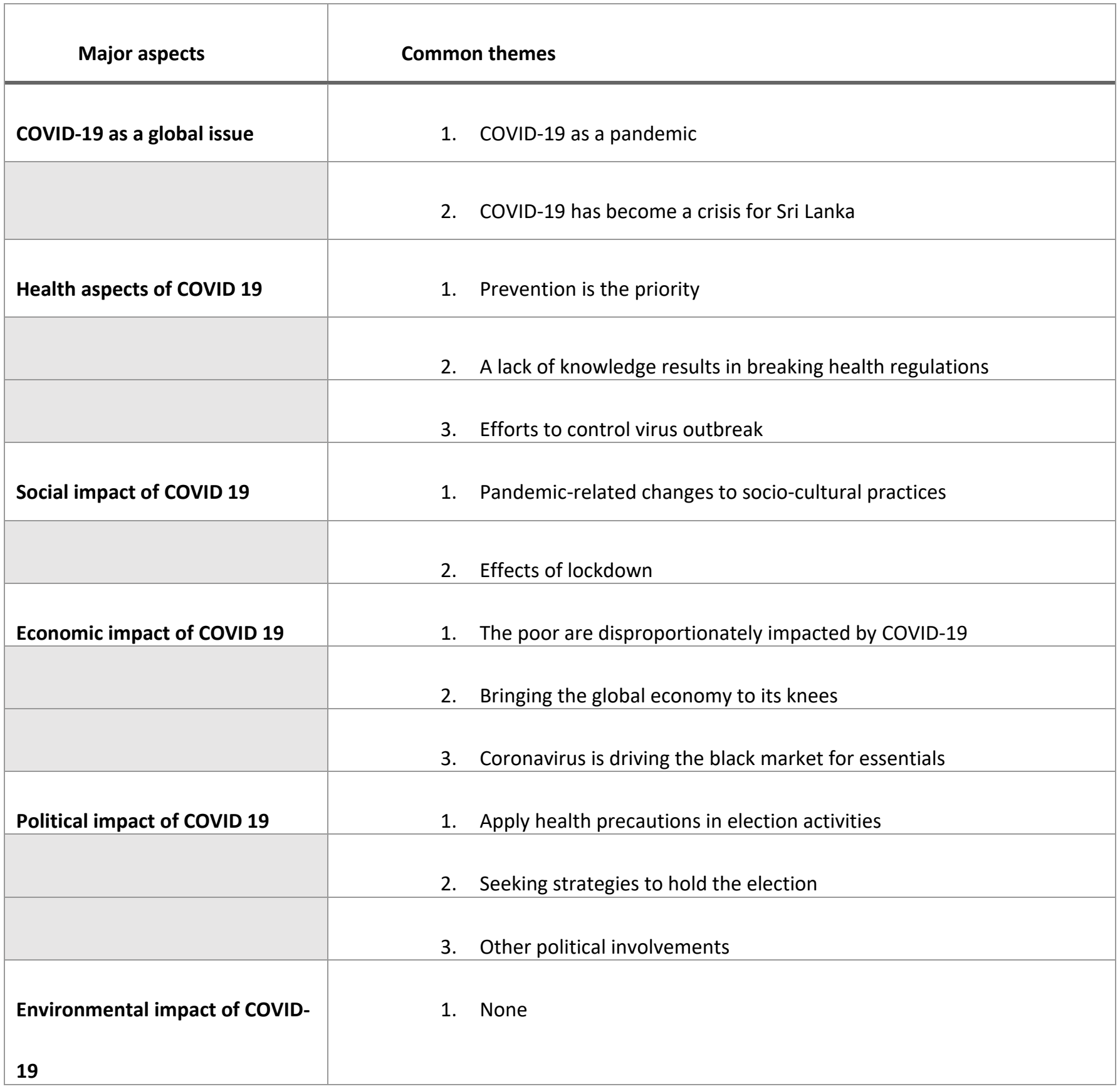

